\title{
An Evaluation of Metal Removal During Wastewater Treatment: the Potential to Achieve More Stringent Final Effluent Standards
}

\author{
D. Ziolko ${ }^{1}$, O.V. Martin ${ }^{2}$, M.D. Scrimshaw ${ }^{1 *}$ and J.N. Lester ${ }^{3}$ \\ ${ }^{1}$ Institute for the Environment, Brunel University, Uxbridge, Middlesex, UB8 3 PH, United \\ Kingdom. \\ ${ }^{2}$ Centre for Environmental Policy, Imperial Collage London, London, SW7 2AZ, United Kingdom. \\ ${ }^{3}$ Centre for Water Science, School of Applied Science, Cranfield University, Bedfordshire, MK43 OAL, \\ United Kingdom. \\ * Tel: $\quad+44(0) 1895267299$ \\ Fax: $\quad+44(0) 1895269761$ \\ e-mail mark.scrimshaw@brunel.ac.uk
}

\begin{abstract}
Metals are of particular importance in relation to water quality, and concern regarding the impact of these contaminants on biodiversity is being encapsulated within the latest water related legislation such as the Water Framework Directive in Europe and criteria revisions to the Clean Water Act in the USA. This review undertakes an evaluation of the potential of two stage wastewater treatment consisting of primary sedimentation and biological treatment in the form of activated sludge processes, to meet more stringent discharge consents which are likely to be introduced as a consequence. The legislation, sources of metals and mechanisms responsible for their removal are discussed, to elucidate possible pathways by which the performance of conventional processes may be optimized or enhanced. Improvements in effluent quality, achievable, by reducing concentrations of suspended solids or biochemical oxygen demand may also reduce metal concentrations although meeting possible requirements for the removal of copper my be challenging.
\end{abstract}

Running head: The removal of metals in wastewater treatment. 


\section{INTRODUCTION}

The concept of sustainable development was first defined in the report of the World Commission on Environment and Development (WCED) "Our Common Future" in 1987 as 'development that meets the needs of the present without compromising the ability of future generations to meet their own needs' (WCED, 1987). This definition introduced two key concepts; that of essential needs for both present and future generations, and that of limitations in meeting them imposed by technology. Water may be considered a renewable resource, and therefore the concept of sustainable development is particularly relevant in the field of water policy, due to its essential role in sustaining life, not only in terms of its available quantity but also in terms of its quality.

Inland freshwater lakes and rivers make up less then $0.01 \%$ of the global water resource (Dudgeon et al., 2005), yet they support approximately 6\% of all known species (Hawksworth and Kalin-Arroyo, 1995) and 40\% of fish diversity (Lundberg et al., 2000). The rate of loss of biodiversity in freshwater ecosystems has been found to be far greater than that observed in terrestrial habitats (Ricciardi and Rasmussen, 1999; Sala et al., 2000). Freshwater species have been observed to be particularly vulnerable to water quality deterioration as they cannot easily disperse across land barriers and must survive ecological changes in-situ (Reid et al., 1992). The risk from biomagnification of pollutants through the food chain is also greater in the aquatic environment in comparison to terrestrial ecosystems since a higher proportion of aquatic species are carnivores (Groombridge and Jenkins, 2000).

Chemical water pollution has been recognized as one of the major factors threating freshwater biodiversity (Malmqvist and Rundle, 2002; Dudgeon et al., 2005). Metals are a group of elements that are of particular concern in relation to water quality, and although 
some metals are essential for physiological function and biochemical processes, the occurrence of the same metals at elevated concentrations, above natural background levels, as a result of anthropogenic activities, can result in toxicological effects (Lester, 1987a; Pane et al., 2003; Hsieh et al., 2004; de Oliveira-Filho et al., 2004; de Schamphelaere et al., 2004; Wang and Rainbow, 2006; Campbell et al., 2008). For example, copper in freshwaters occurs naturally at up to $30 \mu \mathrm{g}^{-1}$, while anthropogenic activities may increase this up to above $100 \mu \mathrm{g} \mathrm{l^{-1 }}$ and in extreme instances to $200,000 \mu \mathrm{g}$ $\mathrm{l}^{-1}$ in mining areas (USEPA, 2007). Cadmium and copper have also been identified as potential endocrine disrupting compounds (EDC) and they are being investigated for endocrine disrupting activities (Birkett and Lester, 2003; Handy, 2003; Henson and Chedrese, 2004; Medesani et al., 2004; Takiguchi and Yoshihara, 2006; Itoh et al., 2008).

A number of metals potentially hazardous to the aquatic environment (cadmium, copper, chromium, lead, mercury, nickel and zinc) are designated by the United States Environmental Protection Agency (USEPA) as priority toxic pollutants (USEPA, 2006). In Europe, cadmium, lead, mercury and nickel are classified under the Water Framework Directive (2000/60/EC) (WFD) as priority substances (Annex X of the WFD), whereas copper, chromium and zinc are designated as potential main pollutants (Annex VIII) (European Commission, 2000).

Crude sewage is known to contain significant concentrations of metals and therefore municipal sewage treatment works (STW), although not designed to do so, are expected to significantly reduce the load of metals discharged to the receiving waters in the final effluent (Lester, 1983). Conventional sewage treatment typically involves two treatment stages: primary sedimentation and biological treatment. Both processes have been found to be capable of removing part of the metal burden from the sewage (Sterrit et al., 1981; 
Rossin et al, 1982a; Sterritt and Lester, 1982; Kempton et al., 1987a,b; Karvelas et al., 2003; Buzier et al., 2006). The objective of this review is to assess the main drivers behind the requirement for removal of metals in wastewater treatment and to evaluate the potential of two stage wastewater treatment utilizing primary sedimentation and activated sludge processes to allow receiving waters to meet increasingly stringent environmental quality standards (EQS). Although it is apparent that removal of metals from effluents will result in their occurrence in sludge produced during treatment, the subsequent fate and behavior of metals during sludge treatment and disposal is beyond the scope of the review. The review concentrates on the activated sludge process as it has been the focus of studies undertaken, probably as a result of its use in urban areas of developed countries. Mechanisms of metal removal together, with factors that may have a significant impact on metal removal efficiency, are discussed, to critically evaluate the possible means by which the performance of unit treatment processes may be enhanced and / or optimized.

\section{WATER RELATED LEGISLATION}

Although water related legislation varies between countries, it has been observed that there are conceptual similarities between that in the United States and Europe (Bouleau, 2008), therefore both the United States and Europe are discussed as examples of integrated water management. Within Europe, previously fragmented water-related legislation was integrated into the Water Framework Directive in 2000 (Kallis and Butler, 2001; Correljé et al., 2007). Article 4a of the Directive sets out environmental objectives for surface waters that include (European Commission, 2000):

- Requirement for "no deterioration" of all surface water bodies 
- Subject to a number of exceptions, a requirement to protect, enhance and restore all waters with the ultimate goal of achieving "good status", both ecological and chemical.

The WFD introduced a "river basin district" (RBD) approach to water management that overrides administrative and territorial boundaries (Le Quesne and Green, 2005). Member States were asked to define each RBD by 2003 and to establish River Basin Management Plans (RBMP) by 2009 that shall ensure compliance with environmental goals set by the Directive. The RBMPs should be fully operational by 2012 with one of the objectives of achieving "good status", being that the concentrations of substances of concern do not exceed the EQSs. These standards are provided as threshold values below which no adverse effect is expected to affect either human health or the environment, taking into consideration dilution characteristics at a particular site and the eco-toxicological effect of the chemicals (Whitehouse, 2001; Borja et al., 2006). In the United States the Clean Water Act of 1977 (CWA) regulates discharges of pollutants into the surface waters. Pursuant to Section 304(a) of the CWA, the US EPA have published water quality criteria (WQC) for contaminants in surface waters that are expected to ensure protection of human health and aquatic life (Russo, 2002; USEPA, 2006). They depend on the designated uses assigned to the particular water body and address both short (acute) and long term (chronic) effects (Minnow Environmental Inc., 2005).

\subsection{Existing and Future Trends in Water Quality Standards}

European Community policy regarding chemical pollution of surface waters was introduced in 1976 by the Council Directive on pollution caused by certain dangerous substances discharged into the aquatic environment of the Community (76/464/EEC) that is also known as the "Dangerous Substances Directive" (DSD). The DSD introduced the concept of List I and List II substances with the objective to eliminate 
discharges of substances from List I and to reduce the pollution caused by the substances from List 2 (European Commission, 1976). In 2006 the DSD was codified (2006/11/EC) is now integrated into the WFD and after a transitional period will be fully repealed in 2013 (European Commission, 2006; Crane et al., 2007).

The new European Community "Strategies against Pollution of Water" were set out in Article 16 of the WFD. In 2001 Decision No 2455/2001/EC of the European Parliament and of the Council established the list of priority substances in the field of water policy that become Annex X of the WFD, identifying 33 priority substances including four metals: cadmium, mercury, lead and nickel. It is required that EQSs for these substances will be established at the European level, however, within this list, cadmium and mercury were designated as priority hazardous substances and are thus specifically targeted for "cessation of emissions, discharges and losses" by 2020, while for nickel and lead, as priority substances, the aim is for a progressive reduction of emissions. The list of priority substances and their EQSs will be reviewed every 4 years (European Commission, 2001; Förstner, 2007). Moreover, Member States are also required to identify candidates for main pollutants from the group of substances listed in Annex VIII of the WFD within each RBD and to set appropriate EQSs for them at the national level (UKTAG, 2007). Within the USA the approach is different, and the recommended WQC published by the USEPA are not legally enforceable standards, but guidance for States and Tribes to derive their own standards. The WQS are subject to triennial reviews and have to be approved by the USEPA (USEPA, 2006).

Current EQSs applied by the Environment Agency of England and Wales (Environment Agency, 2008) together with WQC recommended by the USEPA (USEPA, 2006) are given in Table 1 and unless otherwise stated, they correspond to the dissolved metal 
concentration. The annual average (AA) and corresponding criterion continuous concentration (CCC) standards address long term effects while standards expressed as maximum allowable concentration (MAC) and criteria maximum concentration (CMC) correspond to the maximum concentration that should not be exceeded at any one time to protect against acute effects. There are some significant differences between the European and US standards, particularly for cadmium and lead, with US values for cadmium being 20 times and for lead 4 times more stringent than in Europe.

Most of the standards take into account issues related to bioavailability by making some allowance for water hardness, and as a general rule, metal toxicity decreases with increasing water hardness. For example, WQC for copper subsequently becomes five times more stringent in soft waters $\left(50 \mathrm{mg} \mathrm{l}^{-1} \mathrm{CaCO}_{3}\right)$ than in hard waters $\left(250 \mathrm{mg} \mathrm{l}^{-1}\right.$ $\mathrm{CaCO}_{3}$ ), as reflected in US water standards (Table 2). These US hardness-dependent criteria may be calculated according to a set formula, whereas European hardness-based EQSs are set for a given range of hardness values, with copper in the UK, for example, being $6 \mu \mathrm{g} \mathrm{l}^{-1}$ where hardness is $50-100 \mathrm{mg} \mathrm{l}^{-1} \mathrm{CaCO}_{3}$, increasing to $28 \mu \mathrm{g} \mathrm{l}^{-1}$ where hardness is above $250 \mathrm{mg} \mathrm{l}^{-1} \mathrm{CaCO}_{3}$, very much reflecting US values. However, to more completely address the actual bioavailability of copper in fresh waters, which is influenced by factors other than hardness, in 2007, the EPA issued updated guideline in deriving copper WQC. The revision is based on utilizing the biotic ligand model (BLM) that derives site-specific water quality criterion. The updated BLM-based WQC may be less stringent, however, in soft waters with low dissolved organic carbon, it may be more stringent than hardness-based WQC (USEPA, 2007). 
Table 1: Current freshwater UK EQS and US WQC for metals $\left(\mu \mathrm{g}^{-1}\right)$.

\begin{tabular}{|c|c|c|c|c|}
\hline & \multicolumn{2}{|c|}{ United Kingdom } & \multicolumn{2}{|c|}{ United States } \\
\hline & AA-EQS & MAC-EQS & $\mathrm{CCC}$ & CMC \\
\hline \multicolumn{5}{|c|}{ European Priority Hazardous Substances } \\
\hline Cadmium & $5(\mathrm{~d})$ & - & $0.25(\mathrm{c})$ & $2.0(\mathrm{c})$ \\
\hline Mercury & $1(\mathrm{~d})$ & - & 0.77 & 1.4 \\
\hline \multicolumn{5}{|c|}{ European Priority Substances } \\
\hline Lead & $10(\mathrm{a})(\mathrm{b})$ & - & $2.5(\mathrm{c})$ & 65 (c) \\
\hline Nickel & 100 (a) & - & $52(c)$ & $470(c)$ \\
\hline \multicolumn{5}{|c|}{ European Main Pollutants } \\
\hline Chromium (VI) & $10(\mathrm{a})(\mathrm{b})$ & - & 11 & 16 \\
\hline Chromium (III) & - & - & $74(\mathrm{c})$ & $570(\mathrm{c})$ \\
\hline Copper & $6(\mathrm{a})$ & $22(a)$ & $9(\mathrm{c})$ & $13(c)$ \\
\hline Zinc & $50(\mathrm{a})(\mathrm{b})(\mathrm{d})$ & $200(\mathrm{a})(\mathrm{b})(\mathrm{d})$ & 120 (c) & 120 (c) \\
\hline
\end{tabular}
(a) hardness related value for $100-150 \mathrm{mg} \mathrm{l}^{-1} \mathrm{CaCO}_{3}$;
(b) freshwaters suitable for Salmonid (game) fish;
(c) hardness related value for $100 \mathrm{mg} \mathrm{l}^{-1} \mathrm{CaCO}_{3}$;
(d) total metal concentration.

Table 2: Calculated freshwater hardness-dependent WQC for dissolved metals $\left(\mu \mathrm{g} 1^{-1}\right)$.

\begin{tabular}{|c|c|c|c|c|c|c|c|c|c|c|c|c|}
\hline \multirow[b]{2}{*}{ Hardness $^{a}$} & \multicolumn{6}{|c|}{ CMC $\left(\mu g 1^{-1}\right)$} & \multicolumn{6}{|c|}{$\operatorname{CCC}\left(\mu g ~^{-1}\right)$} \\
\hline & 1 & 50 & 100 & 150 & 200 & 250 & 1 & 50 & 100 & 150 & 200 & 250 \\
\hline Cadmium & 0.02 & 1 & 2 & 3 & 4 & 5 & 0.01 & 0.15 & 0.25 & 0.33 & 0.4 & 0.5 \\
\hline Lead & 0.35 & 30 & 65 & 100 & 140 & 170 & 0.01 & 1.2 & 2.5 & 3.9 & 5 & 7 \\
\hline Nickel & 9.5 & 260 & 470 & 660 & 840 & 1020 & 1 & 30 & 52 & 73 & 95 & 115 \\
\hline $\begin{array}{c}\text { Chromium } \\
\text { III }\end{array}$ & 13 & 323 & 570 & 800 & 1000 & 1200 & 1.7 & 42 & 74 & 105 & 130 & 160 \\
\hline Copper & 0.2 & 7 & 13 & 20 & 26 & 32 & 0.18 & 5 & 9 & 13 & 16 & 20 \\
\hline Zinc & 2.4 & 65 & 120 & 165 & 210 & 255 & 2.4 & 65 & 120 & 170 & 212 & 260 \\
\hline
\end{tabular}


In June 2008 the European Parliament approved final amendments to the Proposal for a Directive on Environmental Quality Standards (2006/0129 COD) also known as the "Directive on Priority Substances" (European Commission, 2008). Proposed EQSs values developed at the EU level for cadmium, lead, mercury and nickel are presented in Table 3.

Table 3: Proposed EU and UK EQS for metals $\left(\mu \mathrm{g}^{\mathrm{l}^{-1}}\right)$ under the WFD.

\begin{tabular}{ccc}
\hline & Proposed AA-EQS & Proposed MAC-EQS \\
\hline European Priority Hazardous Substances & $<0.45-1.5$ (a) \\
\hline Cadmium & $<0.08-0.25$ (a) & 0.07 \\
Mercury & 0.05 & - \\
\hline European Priority Substances & & - \\
\hline Lead & 7.2 & - \\
Nickel & 20 & 32 \\
\hline European Main Pollutants & & - \\
Chromium (VI) & 3.4 & - \\
Chromium (III) & 4.7 & \\
Copper & $1-28$ (a) & \\
Zinc & $8-125$ (a) (total) & \\
\hline
\end{tabular}

(a) hardness related values;

Within Europe as a result of the new Directive on Priority Substances, the EQS for cadmium will become hardness related, whereas those for lead and nickel will no longer take account of this factor. Another change will be that EQSs for cadmium and mercury will be based on dissolved metal concentrations, rather than total. Values for proposed UK EQSs for Annex VIII substances (chromium, copper and zinc) are derived by the UK Technical Advisory Group (UKTAG, 2007). Due to the lack of adequate data, standards for copper and zinc remained unchanged and these substances were not recommended as Specific Pollutants in the first round of RBPs. Only in the case of chromium have new, more stringent standards been suggested (UKTAG, 2007). With the 
introduction of the new EU EQSs under the WFD the difference between the US and EU cadmium standard will decrease however, the EQS for lead will remain more stringent in US, although the EPA is working on new criterion for lead and this may change substantially in the future (USEPA, 2006).

\section{SOURCES AND OCCURANCE OF METALS IN WASTEWATER}

Historically, sources of heavy metals in wastewater have been strongly linked to industrial emissions (Klein et al., 1974; Davis et al., 1975; Lester et al., 1979; Stoveland et al., 1979a; Koch et al., 1982; Yost and Wukasch, 1983; Stonebrook et al., 1984). Recent studies have, however, indicated that the significance of trade emissions is decreasing in some areas, with analysis of the crude sewage from thirty English STW serving a range of catchments (rural, urban, industrial and/or mixed) revealing no apparent correlation between metal concentrations in crude sewage and industrial input (Rule et al., 2006a). Such changes have increased the relative significance of diffuse sources such as domestic use, urban and agricultural runoff and small businesses as contributors to the heavy metal load entering municipal STW (Bergback et al., 2001; Rule et al., 2006a, b). Heavy metals are ubiquitous in nature and are almost always detectable in untreated crude wastewaters. Some concentrations of metals found in STW influents from around the world are given as an illustrative example in Table 4.

The Henriksdal STW serves more than 630,000 people along with discharges from around 200 activities requiring a permit, according to environmental legislation, along with other minor activities such as dentists, art schools and car washes. The sewerage system is both combined sewers (foul and storm waters) and duplicate (separate foul and storm sewer systems). Approximately 4\% of heavy metals in the wastewater were found to originate from point sources such as large enterprises (Sorme and Langerkvist, 2002). 
The STW in Thessaloniki serves approximately 1 million inhabitants with 5-10\% of the total flow being contributed by small businesses. It also receives the majority of the local urban runoff (Karvelas et al., 2003). Takatori STW is given as an example of a small treatment plant that serves a community of less than 10,000 people with no industry, thus representing only domestic input (Mitsuo et al., 1991). In Ribeirao Preto the STW serves approximately half a million people and a diverse range of over 1,000 industrial activities. Although 95\% of these are regarded as small businesses, a significant number of them may contribute to the metal load including metallurgy (159), medical-hospital and chemical (175) and food industries (163) (Oliveira et al., 2007).

Table 4: Mean metal concentrations $\left(\mu \mathrm{g} 1^{-1}\right)$ in wastewater.

\begin{tabular}{|c|c|c|c|c|c|c|c|c|}
\hline Location & $\mathrm{Cu}$ & $\mathrm{Cr}$ & $\mathbf{N i}$ & $\mathrm{Pb}$ & $\mathrm{Cd}$ & $\mathbf{H g}$ & $\mathrm{Zn}$ & Reference \\
\hline Oxford, UK & 161 & 63 & 40 & 158 & 6 & - & 1650 & $\begin{array}{c}\text { Lester et al., 1979; } \\
\text { Stoveland et al., 1979a }\end{array}$ \\
\hline $\begin{array}{l}\text { Whitlingham } \\
\text { Norwich, UK }\end{array}$ & 289 & 25.4 & 26 & 50 & 2.2 & 1.6 & 346 & Lester, 1987a \\
\hline $\begin{array}{c}\text { Henriksdal, } \\
\text { Stockholm, Sweden }\end{array}$ & 78 & 4 & 6.2 & 3.6 & 0.23 & 0.1 & 150 & $\begin{array}{l}\text { Sorme \& Lingerkvist, } \\
2002\end{array}$ \\
\hline $\begin{array}{c}\text { Thessaloniki, } \\
\text { Greece }\end{array}$ & 79 & 40 & $77 *$ & 39 & 3.3 & - & 470 & Karvelas et al., 2003 \\
\hline Takatori, Japan & 64 & 5.1 & 6.7 & 18 & 0.9 & - & 224 & Mitsuo et al., 1991 \\
\hline $\begin{array}{l}\text { Ribeirao Preto, } \\
\text { Sao Paulo, Brazil }\end{array}$ & 17 & 6.9 & - & 37 & 0.2 & 0.1 & 79 & Oliveira et al., 2007 \\
\hline $\begin{array}{c}\text { Survey of } 30 \\
\text { different STW, UK }\end{array}$ & 78 & 12 & 14 & 25 & 0.8 & 0.5 & 155 & Rule et al., 2006a \\
\hline
\end{tabular}

It is clear that there is wide variation in metal concentrations in the crude wastewaters between sites. These variations range up to over an order of magnitude (Rule et al., 2006a) with the greatest variations reported for zinc and copper (Chipasa, 2003; Oliveira et al., 2007) and the smallest for cadmium and lead (Oliveira et al., 2007). Wherever there is detailed knowledge of the catchment activities these variations may be easy to explain; 
at Whitlingham STW, Norwich (UK) it is known that, at the time of sampling, a local chemical company discharged mercury principally in the form of mercury halides (with copper as a co-contaminant) which would be a likely explanation for the high concentrations of both metals observed (Goldstone et al., 1990a, b). However, in many cases, there is insufficient evidence known to permit comment on concentrations such as those of nickel and cadmium in Thessaloniki (Karvelas et al., 2003) or copper and zinc in Oxford (Lester et al., 1979; Stoveland et al., 1979a). Nevertheless, in developed countries, concentrations of metals of concern in wastewaters have generally decreased in comparison to the late 1970s, most likely due to the closure of heavy industries, improved effluent pre-treatment technologies and more stringent regulation of trade effluents. This decreasing trend of metal discharge has also been observed for cadmium, chromium, copper, mercury and lead found in sludges (Sorme and Langerkvist, 2002) when compared to values observed in 1970s (Sterritt and Lester, 1980a; Sterritt and Lester 1981a; Lester et al., 1983; Lester 1987a). However, there is still the possibility of a significant impact on metal concentration of crude sewage from industry, especially in developing countries (Cheng, 2003).

The inputs of metals from industrial point sources are generally well characterized and relatively easy to control and therefore understanding contributions from diffuse sources is of increasing importance if loads of metals to STW are to be further reduced. It is therefore necessary to distinguish between, and accurately estimate all significant sources of such emissions if source control is to be used to facilitate compliance with increasingly stringent regulations for both effluent and sludge quality. The relative contributions of various known sources of metals transported to STW have been estimated from published data and compared with actual measured values in crude sewage at Henriksdal STW (Sorme and Lindqvist, 2002). Although, cultural, climatic or other differences 
between Sweden and other countries, such as the use of copper for roofing or the use of studded tyres, may influence the relative contributions of each metal, other sources such as leaching from pipes and taps (copper), food and galvanized material (zinc), carwashes (zinc, lead, chromium and cadmium), drinking water (nickel) and dental amalgam (mercury) would appear to be of more international relevance. During this study, fluxes of zinc and copper appeared to be well understood, since $100 \%$ and $112 \%$ respectively of measured values were accounted for, while sources for other metals, in particular chromium (25\%), lead (55\%) and cadmium (59\%), were not well identified, although underestimation of lead and mercury may be explained by missing values from pipe sediments. However, although contributions from this source may be significant, and are expected to be higher in countries where lead plumbing is still in use, estimation was technically not possible. Additionally, household stainless steel products, not taken into consideration in the Swedish study, can be an important source of chromium and nickel (Comber and Gunn, 1996).

The copper flux presented by Sorme and Lindqvist (2002) has been criticized by Landner and Reuther (2004). They argued that copper released from plumbing (both residential and commercial) appeared to be overestimated when compared to other research performed on the same catchment (Landner et al., 2000; Bergbäck et al., 2001). However, it is well documented that corrosion of pipes is a primary contributor of copper to STW with more impact from residential areas (68\% of total) than from commercial (54\%) and industrial (35\%) (Bouley and Edwards, 2000) and pipework can also be a significant source of lead (Isaac et al,. 1997) and zinc (Koch and Rotard, 2001). The relatively high contribution to the load of copper from roofing material has been questioned as other studies demonstrated that only $10-20 \%$ of copper from fresh runoff from the roofs reaches STW (the rest is retained in soil and concrete), while runoff from the traffic 
sector was said to be underestimated (Bartling et al., 2002). It is, however, evident that while relative contributions of these sources for copper might change, urban runoff is a significant source of copper, lead and zinc (Legret and Pagotto, 1999; Comber and Gunn, 1996).

These examples demonstrate how difficult it is to quantify trace metal fluxes to STW and highlight that the understanding of the sources is insufficient to be used efficiently to reduce inputs. Moreover, most of the data available is based on total metal concentrations, with no details about phase distribution and/or speciation, which are possibly one of the most important factors influencing the removal of metals in wastewater treatment (Kempton et al.,1983; Rudd et al., 1983a; Lawson et al., 1984a; Kempton et al., 1987a,b). Achieving the reduction in metal fluxes to STW may be necessary to be able to both comply with increasingly stringent discharge limits and to continue to reuse sludge as a fertilizer. However, lining or replacing copper pipes, removing pipe sediments or separating foul and storm sewer systems would require considerable infrastructure investment. Source control of known contributors to the metal load, such as carwashes, dentists and other small enterprises would probably significantly contribute to diminishing the discharge of metals to sewer. However, wastewater utility companies have little ability to directly influence the amount of pollutants reaching STW since it is beyond their management control and therefore reduction will depend on the action of the wider society including regulators, authorities, manufacturers and consumers (Sorme et al., 2003). 


\section{FATE OF METALS IN CONVENTIONAL SEWAGE TREATMENT}

Conventional sewage treatment consists of up to three main treatment stages, primary sedimentation, secondary (biological) treatment and when required there are a range of tertiary treatment options that can be implemented as a 'polishing step' to further improve effluent quality (Birkett and Lester, 1999). Domestic STW are designed to remove suspended solids, the biodegradable organic matter and nutrients (nitrogen and phosphorus) loads from the wastewater and thus any removal of toxic elements should be considered as a fortuitous benefit of these processes (Sterritt and Lester, 1981b; Lester, 1983; Arundel, 2000; Metcalf and Eddy, 2004; Sonune and Ghate, 2004; Gray, 2005). It is therefore important to understand the exact mechanisms governing the behaviour of metals during each stage of sewage treatment to determine how to operate STW to make the removal of metals more efficient and robust (Lester, 1983).

\subsection{FATE OF METALS IN PRIMARY TREATMENT}

Primary sedimentation can significantly contribute to the overall efficiency of metal removal at STW and by reducing the heavy metal load to the subsequent biological treatment, minimise the possibility of impairment of these processes as a result of metal toxicity to the microorganisms (Barth et al, 1965; Lester et al., 1979; Sterritt and Lester 1980b). The metal removal process at this stage is physical and depends upon the presence of metal in an insoluble, settleable (associated with particulate matter or precipitated) or potentially settleable form (Oliver and Cosgrove, 1974; Kempton et al., 1987a,b) and therefore the principal factors controlling metal removal at this stage are (Lawson et al., 1984b, c, d; Kempton et al., 1987a):

- metal speciation in crude sewage (most importantly partitioning between the particulate and dissolved phases),

- efficiency of suspended solids removal, 
- removal of BOD (as an indicator of residual complexation capacity).

\subsubsection{METAL SPECIATION IN PRIMARY TREATMENT}

As in natural waters, metals in wastewaters may occur as dissolved (free ion or dissolved organic/inorganic complex), colloidal or particulate species (Landner and Reuther, 2004). However, due to much higher concentrations of solids and soluble organic matter, crude sewage is a much more complex matrix and determination of specific chemical species is difficult to perform (Rossin et al., 1982a; Sterritt and Lester, 1984a, b; Kempton et al., 1987a, b; Scancar et al., 2000). It is therefore not surprising that in such a system, with a large complexation capacity, free metal ions are rare, and the metals are more likely to occur as organo-metallic complexes (Lawson et al., 1984b, c, d; Sterritt and Lester, 1984a). It has been suggested that the majority of metals in wastewater can be viewed as being associated with three major sub-fractions (Kempton et al., 1987b):

- surface-bonded organic ligands, which is effectively organic suspended matter, determined as volatile suspended solids (VSS),

- insoluble matter, which is inorganic in nature, and determined as non-volatile suspended solids (NVSS)

- soluble organic ligands, which are dissolved, and may be determined as soluble chemical oxygen demand (COD).

Copper, lead and zinc have been found to be primarily associated with the NVSS fraction suggesting their presence as an insoluble species, whilst nickel, cadmium and chromium were distributed between different fractions. The speciation of the metal may be affected by many factors such as influent COD, metal concentration and influent suspended solids concentration as well as $\mathrm{pH}$, redox potential, hardness, alkalinity and dissolved oxygen concentration. All parameters are interrelated and highly site specific and may 
ultimately have an impact on removal efficiency (Lester, 1983; Lawson et al., 1984a; Lester, 1987b).

Any factor affecting the solubility of metal is likely to have a significant impact on their removal efficiency in primary sedimentation. Distribution of the metals between the solid and the liquid phase can vary not only from site to site (Table 5) but also temporally at the same STW (Lester, 1983; Goldstone et al., 1990b).

Table 5: Percentage of dissolved metal fraction in crude wastewater.

\begin{tabular}{ccccccccc}
\hline Location & $\mathbf{C u}$ & $\mathbf{C r}$ & $\mathbf{N i}$ & $\mathbf{P b}$ & $\mathbf{C d}$ & $\mathbf{H g}$ & $\mathbf{Z n}$ & Reference \\
\hline Whitlingham, UK & 9 & 63 & 71 & $\sim 15$ & 70 & 7 & 35 & $\begin{array}{c}\text { Goldstone et al., } \\
\text { 1990a, b, c }\end{array}$ \\
Thessaloniki, Greece $*$ & $<10$ & $<10$ & 80 & $<5$ & $<15$ & - & $<10$ & Karvelas et al., 2003 \\
Paris, France & $<27$ & $<27$ & 78 & $<27$ & 86 & - & - & Buzier et al., 2006 \\
\hline
\end{tabular}

* Estimated from Karvelas et al., 2003, Fig 2.

However, each metal behaves differently, with lead and copper predominantly found in the particulate form, which along with chromium, were found to be the least mobile metals in primary sludges (Lake et al., 1989, Scancer et al., 2000; Alvarez et al., 2002). The most soluble metal is nickel and this observation is supported by data on partition coefficients (Karvelas et al., 2003). A low affinity for particles, together with low stability constants for nickel complexes (most of the nickel can be found in the water soluble, exchangeable fraction) makes it the most mobile metal of all (Scancer et al., 2000; Alvarez et al., 2002; Sorme and Lanqvist, 2002). Zinc has also been found to be bound mostly with the readily exchangeable fraction (Scancer et al., 2000; Alvarez et al., 2002) but it has a higher affinity for particles and thus a much higher proportion of zinc is typically associated with particles (Karvelas et al., 2003). Mobile metals such as nickel and zinc can be readily solubilized by organic ligands present in wastewater (Sterritt and 
Lester, 1984a). Copper is also known to have a strong affinity for dissolved organic ligands (Lester, 1987b). Complexation of metals by dissolved ligands may lower their affinity for the surfaces of settleable particles and enhance their mobility. Moreover, such complexes are much more stable than solid phase complexes and once formed tend to pass through STW unaffected by treatment (Sterritt and Lester, 1984a; Landner and Reuther, 2004). Both natural and synthetic chelating agents such as EDTA or NTA have been found to be important in controlling nickel, zinc and copper partitioning (Stoveland et al., 1979b, c; Obeng et al., 1981; Obeng et al., 1982; Rossin et al., 1982b, c; Rossin et al., 1983a; Lawson et al., 1984a; Hunter et al., 1985; Stephenson et al., 1985; Landner and Reuther, 2004; Ridge and Sedlak, 2004).

The distribution between the solid and the liquid phase has been demonstrated to be unaffected by influent metal concentration. Comparison of data from five different locations found no correlation between influent metal concentrations and the percentage removal for chromium, copper, lead, nickel and zinc in the primary treatment stage (Lester, 1987b). There is, however, evidence that overall removal efficiency of the whole STW can be influenced by influent metal concentration and it has been reported that the higher the concentration the better the overall removal (Cheng et al., 1975; Neufeld and Hermann, 1975; Stoveland and Lester, 1980; Chipasa, 2003). It has also been observed that up to 10 fold variations in the influent concentrations of some metals over a short period of time did not affect removal efficiency, which remained fairly constant over a longer period of time (Olivier and Cosgrove, 1974; Rossin et al., 1983b). The most significant factor reducing the solubility of cadmium, chromium and copper, and hence increasing their removal, was found to be influent suspended solid concentration and this is hypothesised to be due to the increased number of possible sites the metals could adsorb to (Kempton et al., 1987a). 


\subsubsection{MECHANISM OF METAL REMOVAL IN PRIMARY TREATMENT}

Very limited removal of soluble metals has been observed during primary sedimentation and as a result the proportion of dissolved to particulate metal in the settled sewage increases (Olivier and Cosgrove, 1974; Lawson et al., 1984a; Yeoman et al., 1989; Ekster and Jenkins, 1996, Santarsiero et al., 1998; Karvelas et al., 2003). However, metal solubility itself is not a reliable guide to the estimation of removal efficiency since their presence in an insoluble form does not guarantee removal (Kempton et al., 1987b). Metals not only have to be present in an insoluble form, but also have to be readily settleable. During primary sedimentation two types of settling mechanism are likely to occur: discrete and flocculent. Discrete settling typically only occurs towards the surface of the tanks, where suspended solids are relatively dilute and settling can be approximated to by Stokes' Law and is related to the particle size, the solid/liquid phase density difference and viscosity. Although Stokes' Law applies to non-flocculating, spherical particles only, it demonstrates that the sedimentation rate increases with the square of a particles diameter (size). Flocculation processes occurring in the lower parts of a tank are beneficial, resulting in an increase in particle size (agglomeration) and thus settling rate (Eckenfelder, 1989; Aarundel, 2000; Lester and Edge, 2001; Metcalf and Eddy, 2004). Although this process occurs naturally in wastewater, it can be also encouraged be addition of chemicals which has been reported to enhance not only the removal of solids, but also metals (Kirk et al., 1988; Poon and Chu, 1999; Semerjian and Ayoub, 2003; Chang, 1995).

Depending on operating parameters, the critical size of suspended solids, above which very little escape in primary effluent, varies from 35 to $125 \mu \mathrm{m}$ which suggests preferential settling of larger particles (Kempton et al., 1987b). Thus it is not surprising that more than $90 \%$ of the particulate metals in the settled sewage are found to be associated with 
particles smaller than $44 \mu \mathrm{m}$ in size (Chen et al, 1974). Therefore, a further reduction in metal concentrations may be achieved by the optimization of the removal of suspended solids below $125 \mu \mathrm{m}$ in size. Suspended solids removal has been shown to be most significantly affected by influent suspended solids concentration, probably due to the increase in flocculation rate. Typically, the removal efficiency of solids increases with an increase in influent solids concentrations (Stoveland and Lester, 1980), however, beyond certain suspended solids content, the removal can be adversely affected due to the phenomena known as "plant overload" (Kempton et al, 1987a). Moreover, although increases in the removal of solids can be observed for each particles size class, it affects the smallest particles most (Kempton et al, 1987b). Surface loading has an opposite effect on solid removal efficiency (Tebbutt and Christoulas, 1975). With the exception of nickel and lead removal tends to decrease with increasing hydraulic loading (Rossin et al., 1983b) similarly with smaller particles affected more significantly than larger (Kempton et al, 1987b). Certain metals are more sensitive to operational changes than others, suggesting that they tend to bind to different solid fractions (Kempton et al, 1987b). Both lead and zinc (Rossin et al., 1983b) and copper and lead (Kempton et al., 1987b) have been observed to be predominantly associated with the smaller $(<35 \mu \mathrm{m})$ fraction. As these three metals have also been observed to be associated with the inorganic fraction (measured as NVSS) in the crude sewage, their behaviour may be controlled by precipitation. Moreover, the NVSS fraction, was less readily removed than the organic, VSS fraction (43\% and 71\% respectively) (Kempton et al, 1987b). However, Kempton et al. (1987a) reported that the removals of cadmium, chromium, copper and nickel were mainly determined by adsorption, whereas that of lead was dominated by precipitation. Zinc was affected by both processes. Therefore, zinc and lead precipitates that may be as low as $0.6 \mu \mathrm{m}$ in size (Barnes, 1975) may be especially difficult to remove in the primary settling process. Particulate nickel was removed efficiently suggesting preferential 
association with larger particles. However, more than $80 \%$ of total nickel was present in the dissolved phase and thus the overall removal of this metal was low (Chen et al., 1974).

At most STW some of the liquors from sludge processing or other processes are returned to the head of the works, before primary sedimentation. However, the impact of such liquors on metal removal has not been extensively studied, although it has been reported that they may be beneficial in influencing partitioning onto solids of some metals, and thus improve their removal (Buzier et al., 2006). A noticeable decrease in soluble metal concentrations for cadmium, chromium, copper, mercury and lead has been reported after addition of returned sludge liquors to the crude sewage, possibly due to the addition of suspended solids and thus increasing sites available for metal binding (Goldstone et al., 1990a, b, c). However, the process of metal partitioning can also be driven by changes in redox potential and this requires investigation. Removal of other metals (nickel and zinc) was unaffected by addition of return liquors. The behaviour of nickel may be explained through complexation by ligands, or due to its low affinity for particles, thus it would be less able to bind than other metals with higher partition coefficient values (Goldstone et al., 1990b). In the case of zinc, several authors have reported that solids are less important in soluble zinc removal, however, the exact mechanism in unknown (Kempton et al., 1987a, Stephenson and Lester, 1987; Goldstone et al., 1990b). A decrease in dissolved metal concentrations has also been observed when sludge filtrate containing ferric chloride was recirculated (Buzier et al., 2006). Ferric chloride is often used as a coagulant to enhance removal of solids and would be expected to increase the removal of metals associated with these solids. It has also been suggested that iron can replace metals in metal-EDTA complexes so they are then free to bind to settleable particles (Ridge and Sedlak, 2004). Other data indicates, however, that 
recirculated anaerobic digester liquors can also increase the dissolved metal fraction (Brown et al. 1973), although in this case the liquors were known to contain high concentrations of dissolved metals and fine particles. Such examples stress the importance of site specific evaluation of the significance of return liquors and their handling on metal removal in primary treatment.

\subsubsection{METAL REMOVAL EFFICIENCY DURING PRIMARY TREATMENT}

Numerous factors influence the removal of heavy metals during primary sedimentation and it is not surprising to find that reported removal efficiencies vary greatly from site to site (Table 6). However, removal efficiencies found at the Oxford STW (Table 7) also illustrates that not only does removal exhibit special variations, but it can also show temporal variation at individual STW. The removal process during primary sedimentation is physical, with minimal removal of dissolved material. The efficiency of solids removal and the chemical species of the metal (soluble or insoluble) are influenced by a range of site specific factors. The removal of suspended solids will be affected by:

- Design, surface loading

- Flow, dry weather or storm

- Influent suspended solids and impact of solids in return liquors.

The chemical species of the metal may depend upon:

- Influent metal concentration

- Influent suspended solids and COD concentrations

- Hardness, alkalinity, $\mathrm{pH}$ and redox potential of the wastewater.

As a result of these factors, the removal rates for metals vary widely, however, it is noteworthy that removal efficiencies generally follow the order: mercury and lead $>$ zinc 
and copper $>$ cadmium and chromium $>$ nickel, demonstrating that the characteristics of each metal also play a significant role in the removal process.

Table 6: Removal efficiencies (\%) in primary treatment at different locations

\begin{tabular}{ccccccccc}
\hline Location & $\mathbf{C u}$ & $\mathbf{C r}$ & $\mathbf{N i}$ & $\mathbf{P b}$ & $\mathbf{C d}$ & $\mathbf{H g}$ & $\mathbf{Z n}$ & Reference \\
\hline USA & 33 & 55 & 15 & 66 & 60 & 57 & 54 & Barth et al., 1965 \\
Canada & 70 & 36 & - & 59 & 25 & 54 & 68 & $\begin{array}{c}\text { Oliver and Cosgrove, } \\
1974\end{array}$ \\
Greece & 27 & 38 & 22 & 21 & 30 & - & 19 & Karvelas et al., 2003 \\
UK & 59 & 60 & 67 & 71 & 67 & 75 & 73 & $\begin{array}{c}\text { Goldstone et al., } \\
\text { 1990a, b, c }\end{array}$ \\
UK & 39 & 20 & 25 & 42 & 23 & - & 38 & $\begin{array}{c}\text { Kempton et al., 1987a } \\
\text { UK }\end{array}$ \\
USA & 71 & 51 & 23 & 73 & 72 & - & 74 & $\begin{array}{c}\text { Lester et al., 1979; } \\
\text { Stoveland et al., 1979a }\end{array}$ \\
USA & 45 & 28 & 21 & 40 & - & - & 41 & Brown et al., 1973 \\
USA & 47 & 39 & 49 & 82 & 41 & - & 47 & Chen et al., 1974 \\
\hline Average & 20 & 29 & 46 & 42 & 20 & - & 18 & Wukasch et al., 1979 \\
\hline
\end{tabular}

(-) no data

Table 7: Removal efficiencies (\%) during primary treatment at Oxford STW

\begin{tabular}{ccccccc}
\hline Metal & $\mathbf{C u}$ & $\mathbf{C r}$ & $\mathbf{N i}$ & $\mathbf{P b}$ & $\mathbf{C d}$ & $\mathbf{Z n}$ \\
\hline $\begin{array}{c}\text { Average removal (\%) } \\
\begin{array}{c}\text { Variation in influent } \\
\text { concentration (\%) }\end{array}\end{array}$ & 71 & 51 & 23 & 73 & 72 & 74 \\
Variation in removal (\%) & 47 & 37 & $0-100$ & 20 & 28 & 14 \\
\hline
\end{tabular}

Lester et al., 1979 and Stoveland et al., 1979a. 


\subsection{FATE OF METALS IN BIOLOGICAL TREATMENT}

Biological treatment can be divided into two processes, a biological reactor and phase separator (Lester, 1987b). Two types of processes can be utilised in biological reactors, either suspended growth (activated sludge) or an attached growth process (trickling filters) (Metcalf and Eddy, 2004). The mechanism of metal removal by the biological film on the trickling filters has been suggested to be not dissimilar to that occurring in the activated sludge biomass (Lester, 1987b), however, as trickling filters have not been extensively studied in terms of metal removal, possibly due to the difficulties in sampling the biomass, the exact mechanism remains yet to be established.

In the activated sludge process, the large variety of species of different micro-organisms (principally bacteria), using oxygen and nutrients, convert (oxidise) biodegradable particulate and dissolved organic matter present in the wastewater into water, carbon dioxide and additional biomass. Those bacteria occur in form of freely suspended agglomerates (flocs) which are later consolidated in the secondary sedimentation tanks. Decanted effluent is then discharged to the receiving waters or is diverted for further treatment whilst sludge is either returned to the reactor or sent for sludge treatment (Lester and Birkett, 1999; Metcalf and Eddy, 2004). Any substances, including dissolved

and particulate metals, which are either adsorbed or absorbed to the biomass, are removed from the effluent with the sludge (Lester, 1987b). The significance of the metals in sewage sludge and the role played by metal speciation in determining environmental impact has been described elsewhere (Lester et al., 1983; Lake et al., 1984; Lester et al,. 1987b; Rudd et al., 1988; Lester and Edge, 2001).

\subsubsection{METAL SPECIATION IN BIOLOGICAL TREATMENT}


The complex and dynamic nature of sewage make it difficult to define the precise chemical forms of the metals present, however, developments in electro-thermal atomisation atomic absorption spectrophotometry (Sterritt and Lester, 1980c) lowered detection limits significantly. With this development it was established that for most metals, the proportion of dissolved to total metal tends to increase through the treatment process (Oliver and Cosgrove, 1974; Goldstone et al., 1990a, b, c; Karvelas et al., 2003). It has also been suggested that most of the soluble metal in sewage is complexed to organic ligands rather than being present in the free, ionic form (Lawson et al, 1984b, c, d). Filtered COD is a measure of the amount of soluble organic compounds in an effluent. Sewage often contains not only natural chelating agents such as proteins and nucleic acids, but also synthetic organic chelating agents of industrial origin such as nitrilotriacetic acid (NTA) and ethylenediamine tetraacetic acid (EDTA) (Stoveland et al., 1979a; Knepper, 2003; Ridge and Sedlak, 2004). Unless the biological processes degrade these compounds, metals complexed to them will not be available for adsorption by the activated sludge flocs and thus escape in the effluent. For example, between 45 and 55\% of zinc was found to be adsorbed onto readily settleable particulates, whilst over $80 \%$ of nickel and lead were found in the soluble phase (Chen et al., 1974). The complexation capacity of the sewage matrix and the influent metal concentrations will therefore both have an impact on removal efficiency (Lester, 1987b).

In the case of chromium, the oxidation state has been found to affect removal efficiency. Chromium normally enters the treatment plant in the hexavalent form, but the trivalent form is more efficiently removed by adsorption to the suspended solids. It has been demonstrated that during aeration trivalent chromium $\left(\mathrm{Cr}^{3+}\right)$ cannot be oxidised to hexavalent chromium $\left(\mathrm{Cr}^{6+}\right)$, but rather that the hexavalent form may be reduced to the trivalent form by organic substrates that act as electron donors (Stasinakis et al., 2003). 
Zinc has been found to be predominantly organically bound, either to biological solids or soluble organic ligands at low concentrations and the lack of influence of suspended solid concentration in mixed liquors is indicative of a mechanism of uptake differing from that exhibited by other metal contaminants (Stover et al., 1976; Goldstone et al., 1990c). Nickel exhibits a lower affinity for sludge flocs than soluble organic ligands in comparison to other metals (Brown and Lester, 1982a). Additionally, as with primary sedimentation, the size distribution of particulates is of importance. Between $15-25 \%$ of particles present in an influent to an activated sludge plant after primary sedimentation were smaller than $8 \mu \mathrm{m}$ in diameter, and whilst, cadmium, chromium, copper, mercury and zinc tend to adsorb preferentially onto larger particles, nickel and lead are mostly associated with smaller particles less likely to settle (Chen et al., 1974).

\subsubsection{METAL TOXICITY IN BIOLOGICAL TREATMENT PROCESSES}

Activated sludge is a complex ecosystem that consists of a wide variety of different species including bacteria, protozoa, rotifers, fungi and algae (Metcalf and Eddy, 2004). Bacteria are particularly important, as they are able to remove dissolved material, including metals, present in the settled sewage (Lester and Birkett, 1999). However, at elevated concentrations, metals may be toxic to the sludge biomass (Sterrit and Lester, 1980b; Madoni et al., 1992; Madoni et al., 1994; and Chua et al., 1999). The metal toxicity depends not only on the intrinsic toxic properties of the specific metal species (Zitko, 1975; Hu et al., 2002), but also on their bioavailability, the suspended solid concentration, sludge age and concentrations of other cations present in the wastewater (Lester, 1987b). It also depends on the particular species of the organisms present since different species have different toxicity thresholds (Lester, 1983; Lester, 1987b), e.g. autotrophic nitrifying bacteria have been found to be generally more susceptible to metal toxicity than heterotrophs (Tomlinson et al., 1966; Hu et al., 2003). As a result, metal induced 
inhibition of growth of certain species results in a decrease in sludge viability, species diversity and a shift in community structure. This in turn may affect the optimum structure of the flocs (Neufeld, 1976) influencing the subsequent suspended solid separation and reducing treatment efficiency (Kelly et al., 2004).

Toxicity of metals to activated sludge is no longer a concern in developed countries due to the decreasing metal concentrations in the crude sewage. Moreover, the activated sludge system, when subject to metal shock load, has been shown to have the ability to recover after a certain period of time referred to as the 'acclimation period' (Mowat, 1976). Subsequent metal shock loads have been found to have a smaller effect on previously acclimated system than on an unacclimated one (Malaney et al., 1959). It has been suggested that acclimation may represent the period of time required to established species which are tolerant to metals, or possess mechanisms able to detoxify metals (e.g. by mutation or synthesis of new enzymes) (Verma et al., 1976; Lester, 1987b).

\subsubsection{MECHANISM OF METAL REMOVAL IN BIOLOGICAL TREATMENT PROCESS}

Metal removal by activated sludge is a complexed process that depends on many interrelated physical, chemical, biological and operational parameters (Rossin et al., 1982b; Rossin et al., 1983b; Stephenson et al., 1987). Possible mechanisms of removal of both, dissolved and particulate metal at this stage of treatment are believed to be (Brown and Lester, 1979);

- Physical entrapment of insoluble metal by the biomass

- Binding of soluble metal to bacterial walls and extracellular polymers

- Active cellular uptake of soluble metal by the bacteria cells

- Volatilisation of metal to the atmosphere. 
It has been hypothesised that the removal of nickel, lead and zinc in the activated sludge process is almost entirely due to the removal of insoluble metals. In the case of cadmium, chromium and copper soluble metal removal mechanisms were found to account for as much as $10 \%$ of the total removal. An investigation of particle size in the activated sludge process revealed that 15 to $25 \%$ of the particles present were less than $8 \mu \mathrm{m}$ diameter, and would therefore not settle readily (Chen et al., 1974), however, the biomass is thought to play an important role by trapping fine particles which then settle with the flocs. It appears that precipitation is important in the removal of some metals, notably lead and trivalent chromium, although it is not evident whether their final removal is dependent on settlement alone or entrapment within the sludge flocs (Sterritt and Lester, 1981b). However, it has been observed that only a very small proportion of insoluble metal settled in the absence of mixed liquor solids, and interaction of precipitated metals with the mixed liquor was a major removal mechanism for most metal. Conversely, nickel exhibits a low affinity for biomass and its main removal mechanism appears to be direct settlement (Stephenson and Lester, 1987). The influence of metal concentration in the settled sewage on precipitation varies between metals. Precipitation is of importance in the removal of copper at high concentrations, but at low concentrations is less important, whilst the reverse has been observed for trivalent chromium (Lester, 1987b).

The flocs of activated sludge have two major components, microbial cells and extracellular polymeric substances (EPS). The EPS is naturally produced by the microorganisms and is found either in the form of highly hydrated capsules, which adhere onto the cell wall, or as loose, soluble slime which causes an increase in the viscosity of the sewage (Lester, 1983). Four different types of sorption sites which are probably involved in the removal of dissolved pollutants have been identified; the EPS, the cell wall, the cytoplasmic membrane and the cytoplasm (Flemming, 1995). The EPS in particular has 
been found very effective in adsorbing metals (Rudd et al., 1983b; Liu et al., 2001), although there is still conflicting information over which fraction of the biomass is more important with regards to metal removal (Brown and Lester, 1982a, b; Spath et al., 1998). The accumulation of metals by the cells of living organisms is a well known phenomenon, and uptake by flocs in the activated sludge appears to be a two-stage process, an initial rapid uptake followed by a slower second phase. The first phase is understood to correspond to a passive adsorption of metal cations to negatively charged sites on the cell surface, whilst the second one appears to be irreversible, active uptake by the cell (Sterritt et al., 1981; Lester, 1983).

Methylation of metals is a well-documented phenomenon and has been shown to occur naturally for mercury and lead (Fatoki, 1997; Meyer et al., 2007, Raposo et al., 2008) as well as for cadmium (Pongratz and Heumann, 1998, Pongratz and Heumann, 1999). Methylated metals exhibit high volatility (Pongratz and Heumann, 1998) and thus may be emitted to the atmosphere. Methylation is typically regarded as a biological process carried out by micro-organisms, however abiotic chemical conversion by humic substances has also been reported (Nagase et al., 1984; Weber, 1993). The actual concentration of methylated metal depends on the equilibrium between methylation and demethylation processes rather than the actual rate of methylated compound synthesis (Gothberg and Greger, 2006). Methyl-mercury has received most scientific interest due to its toxicity to higher aquatic organisms and humans (Michalke et al., 2000). The majority of biomethylation processes are anoxic (Lester, 1987b; Olson et al., 1989; Bubb et al., 1991; Croston et al., 1996; Birkett and Lester, 2005; Shoham-Frider, 2007) Aerobic conditions during activated sludge process are expected to favour demethylating bacteria, although the high content of organic matter and relatively high temperature may increase the rate of methylation. Nonetheless, mercury methylation has been reported during 
aerobic wastewater treatment, however, it was unclear whether the products were volatilized or taken up by the solids (Goldstone et al., 1990b). Volatilization of elemental mercury and mercury mecaptide have also been reported (Lester, 1987b), however, it might be concluded that volatilization of metals in a continuously operating full-scale aerobic activated sludge plant is generally considered insignificant and is of minor importance (Lester, 1987b; Goldstone et al., 1990b).

The aim of the activated sludge process is to produce a final effluent which has a low suspended-solids concentration as well as low BOD. The BOD of the effluent is a measure of the potential pollution by organic substances expressed in terms of the oxygen required by microorganisms to aerobically biodegrade such matter. It also gives an indication of the complexing capacity of an effluent, and therefore minimising the BOD aids in reducing metal concentrations in the effluent. In order to produce an effluent with a low BOD, the specific growth rate of bacteria (time required for the population to double) must be maintained as slow as possible. The growth of bacteria in the activated sludge process can be controlled in two ways. The dilution ratio between sewage and returned activated sludge will determine the amount of 'food' available for the bacteria, therefore limiting their growth. Equally, the bacteria are only able to grow at the same rate as they are being lost from the system. Only a small amount of bacteria are lost in the clarified effluent and sludge wastage can be easily controlled allowing most of the sludge to be recycled (Lester and Birkett, 1999). Removal efficiency will be influenced by operating parameters such as the stirred sludge volume index (SSVI) and suspended solids removal, physical and chemical factors such as the particle size, temperature, $\mathrm{pH}$, metal concentration and concentration of complexing agents, and biological factors such as the concentration of extracellular materials. 
The time bacteria remain in the activated sludge plant is referred to as sludge age or solids retention time (SRT) and is usually 4 to 9 days, however, when plants are nitrifying, this will be in the range 8 to 12 days with denitrification and enhanced nutrient removal processes operating at up to 20 day sludge ages. Bacteria grow more slowly at longer sludge ages and use much of the organic material for cell maintenance rather than production of new cells. Additionally, suspended solids at higher sludge ages often exhibit superior settling characteristics (Lester, 1983). The sludge age therefore encompasses many factors which will in turn influence metal removal such as the SSVI, the mixed liquor suspended solids concentration (MLSS) and the effluent COD (Stoveland and Lester, 1980; Lester, 1987b). Removals of copper, nickel and zinc were found to be highest when the effluent COD was lowest, whilst removal efficiency of chromium increased with increasing MLSS, which in turn tends to increase with increasing sludge age, as less micro-organisms are wasted (Sterritt and Lester, 1981b; Stephenson et al., 1987). Whilst longer sludge ages appear to offer opportunities to optimise metal removal efficiency, at higher sludge ages complexing agents have been found to be generated in the activated sludge plant, potentially limiting the amount of metals that can be removed (Sterritt and Lester, 1980d). Longer sludge ages have also been found to be accompanied by changes in the surface properties of the suspended flocs, which may in turn influence metal removal efficiency, with sludge surfaces becoming more hydrophobic and less negatively charged (Liao et al., 2001). Solubilisation of cadmium, copper, mercury and lead has been observed during activated sludge treatment, and it has been suggested that, where metal ions are adsorbed to extracellular polymers, oxidation of the polymers in the activated sludge plant may result in either the accumulation of metals by the cell or release of metal ions back into the effluent (Lawson et al., 1984c, d; Rudd et al., 1984). 


\subsubsection{METAL REMOVAL EFFICIENCY IN BIOLOGICAL TREATMENT}

Removal efficiencies from locations worldwide are presented in Table 8 and these demonstrate wide variation, however, as with observations on removal in primary treatment, there is evidence that the characteristics of the metal play a role, with mercury demonstrating the highest removal efficiency followed by lead and zinc $>$ copper and chromium $>$ cadmium $>$ nickel. Removal also demonstrates temporal variation as shown for the removal efficiencies observed in the activated sludge plant of Whitlingham STW (Norwich) in 1986 (Table 9). This data illustrates that removal efficiencies do not always follow the order highlighted in Table 10, as copper was more effectively removed than other meals in this case, and it also shows the wide temporal variation that can occur in removal rates, with variation of above $100 \%$ being observed for cadmium, nickel and zinc over the twelve day sampling period. The mechanisms which control removal during secondary treatment are binding to biological solids and subsequent removal in secondary settlement. Factors influencing these processes are:

- Sludge age, resulting in low effluent BOD and improved settling of sludge flocs

- Physical trapping of precipitates in the sludge floc matrix

- Binding of metal by extracellular polymers

- In capsular form, attached to the cell, aid removal

- When free of the cell, may increase the soluble faction of metal

- Accumulation of metals by the cells

\section{THE POTENTIAL TO REMOVE METALS}

There is a paucity of recent studies reporting removal efficiency of metals in the activated sludge process. However, indications are that in developed countries the concentrations of metals of concern in the crude sewage have decreased since the 1980s. An estimation of the potential for removal, and resulting final effluent quality, is undertaken here on the 
Table 8: Removal efficiencies (\%) in AS plants at different locations

\begin{tabular}{ccccccccc}
\hline Location & $\mathbf{C u}$ & $\mathbf{C r}$ & $\mathbf{N i}$ & $\mathbf{P b}$ & $\mathbf{C d}$ & $\mathbf{H g}$ & $\mathbf{Z n}$ & Reference \\
\hline Canada & 60 & 54 & 1 & 79 & 50 & 62 & 50 & $\begin{array}{c}\text { Oliver and Cosgrove, } \\
1974\end{array}$ \\
UK & 79 & 33 & 61 & 73 & 63 & - & 78 & $\begin{array}{c}\text { Lester et al., 1979; } \\
\text { Stoveland et al., 1979a }\end{array}$ \\
USA & 77 & 82 & 41 & 53 & 47 & 72 & 59 & $\begin{array}{c}\text { Chen et al., 1974 } \\
\text { USA }\end{array}$ \\
Switzerland & 25 & 57 & 21 & 56 & 39 & 69 & 65 & $\begin{array}{c}\text { Esmond and Petrasek, } \\
1974\end{array}$ \\
\hline Average & $\mathbf{5 5}$ & $\mathbf{5 5}$ & $\mathbf{2 8}$ & $\mathbf{5 8}$ & $\mathbf{4 1}$ & $\mathbf{6 8}$ & $\mathbf{5 8}$ & \\
\hline
\end{tabular}

(-) no data

Table 9: Removal efficiencies (\%) in the activated sludge plant in Norwich, UK

\begin{tabular}{cccccccc}
\hline Metal & $\mathbf{C u}$ & $\mathbf{C r}$ & $\mathbf{N i}$ & $\mathbf{P b}$ & $\mathbf{C d}$ & $\mathbf{H g}$ & $\mathbf{Z n}$ \\
\hline Average removal & 61 & 50 & 15 & 31 & 18 & 47 & 15 \\
Standard deviation & 10 & 77 & 173 & 77 & 127 & 35 & 163 \\
\hline
\end{tabular}

Goldstone et al., 1990a, b, c.

basis of published data on the influent wastewater metal concentrations and removal efficiencies observed in both primary and activated sludge treatment plants, in order to identify metals for which there may be difficulties in meeting more stringent EQSs. To undertake this comparison, both the most and the least effective removal efficiencies found for primary sedimentation (Table 6) and activated sludge process (Table 8) were applied to more recently reported metal concentrations in crude sewage from Stockholm, Thessaloniki, Ribeirao Preto and the UK STW survey (Table 5). This modeling exercise is a first approximation of what may be best and worst case removal, and does not consider dilution in receiving waters, but compares projected concentrations in the effluent with the EQSs. It should be noted that while these calculations are based on total metal concentrations, most of the water quality standards correspond to the 
dissolved metal concentrations, however, since the metals present in the final effluent occur predominantly in the soluble form, this is not likely to significantly influence the outcome of the analysis. The output indicates that meeting more stringent standards with conventional processes only may be more challenging for some metals than for the others (Table 10).

Table 10: Estimated best and worst case concentrations of metals $\left(\mu \mathrm{g}^{1^{-1}}\right)$ in final effluent at four locations.

\begin{tabular}{|c|c|c|c|c|c|c|c|c|c|}
\hline \multicolumn{3}{|l|}{ Element } & $\mathrm{Cu}$ & $\mathrm{Cr}$ & $\mathbf{N i}$ & $\mathbf{P b}$ & $\mathrm{Cd}$ & $\mathrm{Hg}$ & $\mathrm{Zn}$ \\
\hline \multirow{3}{*}{ EQS (a) } & \multicolumn{2}{|c|}{ Proposed - EU } & 6 & 3.4 & 20 & 7.2 & 0.15 & 0.05 & 50 \\
\hline & \multicolumn{2}{|c|}{$\mathrm{EU}(\mathrm{UK})$} & 6 & 10 & 100 & 10 & 5 & 1.00 & 50 \\
\hline & \multicolumn{2}{|l|}{ USA } & 9 & 11 & 52 & 2.5 & 0.25 & 0.77 & 120 \\
\hline \multirow{3}{*}{$\begin{array}{l}30 \text { STW, } \\
\text { UK } 2006\end{array}$} & \multicolumn{2}{|c|}{ Crude sewage } & 78 & 12 & 14 & 25 & 0.80 & 0.50 & 155 \\
\hline & \multirow{2}{*}{$\begin{array}{l}\text { Final } \\
\text { effluent }\end{array}$} & Best & 4.8 & 0.9 & 1.8 & 0.9 & 0.08 & 0.04 & 8.9 \\
\hline & & Worst & 47 & 5.8 & 12 & 14 & 0.60 & 0.09 & 78 \\
\hline \multirow{3}{*}{$\begin{array}{l}\text { Stockholm } \\
\text { STW, } \\
\text { Sweden } \\
2002\end{array}$} & \multicolumn{2}{|c|}{ Crude sewage } & 78 & 4.0 & 6.2 & 3.6 & 0.23 & 0.10 & 150 \\
\hline & \multirow{2}{*}{$\begin{array}{l}\text { Final } \\
\text { effluent }\end{array}$} & Best & 4.8 & 1.6 & 0.8 & 0.1 & 0.02 & 0.01 & 8.6 \\
\hline & & Worst & 47 & 2.9 & 5.2 & 2.0 & 0.17 & 0.02 & 76 \\
\hline \multirow{3}{*}{$\begin{array}{l}\text { Thessaloniki } \\
\text { STW, } \\
\text { Greece } \\
2001 \\
\end{array}$} & \multicolumn{2}{|c|}{ Crude sewage } & 79 & 40 & 77 & 39 & 3.3 & - & 470 \\
\hline & \multirow{2}{*}{$\begin{array}{l}\text { Final } \\
\text { effluent }\end{array}$} & Best & 4.8 & 16 & 9.9 & 1.5 & 0.34 & - & 27 \\
\hline & & Worst & 47 & 29 & 65 & 22 & 2.5 & - & 239 \\
\hline \multirow{3}{*}{$\begin{array}{l}\text { Ribeirao } \\
\text { Preto STW, } \\
\text { Brazil } 2007\end{array}$} & \multicolumn{2}{|c|}{ Raw sewage } & 17 & 6.9 & - & 37 & 0.20 & 0.10 & 79 \\
\hline & \multirow{2}{*}{$\begin{array}{l}\text { Final } \\
\text { effluent }\end{array}$} & Best & 1.0 & 2.7 & - & 1.4 & 0.02 & 0.01 & 4.5 \\
\hline & & Worst & 10 & 4.7 & - & 21 & 0.15 & 0.02 & 40 \\
\hline
\end{tabular}

(a) values from Table 1 and Table 4.

Concentrations of chromium, nickel and mercury entering STW in the crude sewage, even without treatment, are already below or very close to the existing European and US water quality standards, except at Thessaloniki STW. Although higher values found in Thessaloniki illustrate the importance of the local context in terms of the concentrations of metals entering a particular STW, it would appear that chromium, mercury and nickel are not of particular concern at present. Zinc does not seem to be of concern either, 
since it is well removed even in the 'worst case removal scenario'. There is a large discrepancy between the US and European environmental standards with regards to cadmium and lead. The proposed European EQS for cadmium is similar to its US equivalent whereas the one for lead will be almost three times less stringent than the USEPA guidance value. Nevertheless, it appears that more stringent standards for zinc, mercury, cadmium, nickel, lead and chromium could possibly be met with optimized conventional treatment processes, although compliance may largely depend on the site specific conditions. It is clear, however, that copper concentrations after primary sedimentation and biological treatment in three out of four examples are very close to environmental standards set for this metal, even when the best case removal efficiency was applied. The relative high proportion of copper in the dissolved phase of final effluents (Table 11) means that further removal to meet more stringent standards may be particularly challenging.

Many regulations relating to the quality of effluents discharged to the environment are based on standards for suspended solids (SS) and biochemical oxygen demand (BOD) (Stander and Theodore, 2008) In the UK, this is generally referred to as the " $30: 20$ standard", corresponding to no more than $30 \mathrm{mg} \mathrm{l}^{-1}$ of SS and $20 \mathrm{mg} \mathrm{l}^{-1}$ of BOD in the final effluent (Lester and Birkett, 1999). During the study at Whitlingham STW (Lester, 1987c) concentrations of dissolved and particulate fractions of metals of interest in the final effluent samples, together with COD and suspended solids data were obtained. These values have been used here to estimate the metal concentrations in the final effluent if more stringent 10:10 and 5:5 SS:BOD standards were to be achieved by the activated sludge process by assuming a reduction in metal concentrations proportional to the reduction in SS for metals associated with solids and the reduction in BOD for the soluble fraction. BOD was estimated as being equal to a fifth of the COD as prescribed 
in the Urban Wastewater Directive (91/271/EEC). Results of these calculations are presented in Table 11.

Table 11: Metal concentrations $\left(\mu \mathrm{g}^{-1}\right)$ in a '10:10' or ' $5: 5$ ' final effluent estimated from values in a '19:13' Whitlingham effluent

\begin{tabular}{|c|c|c|c|c|c|c|c|}
\hline & Cd & $\mathrm{Cr}$ & $\mathrm{Cu}$ & $\mathrm{Hg}$ & $\mathbf{N i}$ & $\mathrm{Pb}$ & $\mathrm{Zn}$ \\
\hline \multicolumn{8}{|c|}{ Measured values for actual SS $=19 \mathrm{mg} \mathrm{l}^{-1}$ and estimated BOD $=13 \mathrm{mg} \mathrm{l}^{-1}$} \\
\hline Total concentration & 0.60 & 9.8 & 70 & 0.27 & 16.0 & 18.0 & 114 \\
\hline Soluble fraction $(\%)$ & 100 & 71 & 82 & 48 & 100 & 47 & 91 \\
\hline Insoluble fraction $(\%)$ & 0 & 29 & 18 & 52 & 0 & 53 & 9 \\
\hline \multicolumn{8}{|c|}{ Estimated values for effluent achieving $\mathrm{SS}=10 \mathrm{mg} \mathrm{l}^{1^{-1}}$ and BOD $=10 \mathrm{mg} \mathrm{l}^{-1}$} \\
\hline Total concentration & 0.46 & 6.8 & 51 & 0.17 & 12.6 & 11.8 & 85 \\
\hline Soluble fraction & 0.46 & 5.3 & 44 & 0.10 & 12.6 & 6.7 & 80 \\
\hline Insoluble fraction & 0 & 1.5 & 7 & 0.07 & 0 & 5.1 & 5 \\
\hline \multicolumn{8}{|c|}{ Estimated values for effluent achieving SS $=5 \mathrm{mg} \mathrm{l}^{-1}$ and BOD $=5 \mathrm{mg} \mathrm{l}^{-1}$} \\
\hline Total concentration & 0.23 & 3.4 & 25 & 0.09 & 6.3 & 5.9 & 43 \\
\hline Soluble fraction & 0.23 & 2.7 & 22 & 0.05 & 6.3 & 3.3 & 40 \\
\hline Insoluble fraction & 0 & 0.7 & 3 & 0.04 & 0 & 2.6 & 3 \\
\hline
\end{tabular}

Whilst the assumption that improved removal of SS and BOD would achieve a proportional reduction of metal concentrations in the insoluble and soluble fractions may overestimate removal efficiencies, the values in Table 13 indicate that for some metals there may be difficulties in meeting more stringent EQSs highlighted in Table 12 simply through improving the performance of AS plants although, note should be taken again that these final effluent concentrations do not take any dilution factor within receiving waters into account. For a '10:10 standard' effluent, estimated concentrations of dissolved cadmium and copper would be above both European and US limits, dissolved chromium and mercury concentrations will exceed proposed European threshold values, while value for dissolved lead would not meet EPA standard. Moreover, totals zinc concentration for the same '10:10 standard' would also fail to comply with existing 
European discharge standards. If '5:5 standards' were to be met, concentrations of all metals, except copper, would be below or approaching the EQSs and dilution in the river should ensure compliance. There is, however, further indication that copper is of particular concern. The estimated concentration is seven and almost four times above the current UK EQS (five and two times of US EQC) if the final effluent met a 10:10 and 5:5 SS:BOD standard respectively. It should be noted however, that copper concentration in the final effluent in this particular example was relatively high $\left(70 \mu \mathrm{g}^{-1}\right)$ in relation to more contemporary values $\left(35 \mu \mathrm{g}^{-1}\right)$ (Karvelas et al., 2003). However, even if this lower final effluent copper concentration was to be used in the calculations, the estimated values would be still significantly above both US and UK EQS. Consideration of the ability of an AS plant to consistently achieve such stringent SS:BOD standards should also be taken into account here. Whilst STWs operating most efficiently may be able to achieve such low concentrations, most conventional treatment plants would probably be at risk of breaching discharge consents resulting from more stringent EQSs.

\section{CONCLUSIONS}

1. Recent and proposed legislation has and will result in increasingly stringent EQSs, and to meet resulting discharge consents, there will be mounting pressure to reduce the concentrations of metals in final effluents.

2. In developed nations, the concentrations of metals in sewage have decreased over recent decades, due to more stringent trade control, and diffuse sources have become significant in determining the metal load entering STW.

3. Influent suspended solids concentration is an important factor controlling the removal of both dissolved and particulate metals during primary sedimentation. 
4. During biological treatment, metals associated with solids are removed through settling with sludge flocs, and dissolved metals through sorption to the biological matrix, although extracellular polymers, when free of the cells may increase the concentration of some dissolved metals, in particular copper, which has a strong affinity for organic ligands.

5. There is a significant spatial and temporal variation in the reported removal rates for a range of metals in both primary and biological treatment. Operational parameters, such as handling of returned liquors during primary sedimentation, or sludge age in biological treatment, influence removal efficiency and improved understanding of their role may be of assistance in optimizing removal of metals.

6. Metals discharged in final effluents are either sorbed to suspended solids, or are in the dissolved phase as complexes associated with the dissolved organic matter, which may be quantified in terms of BOD. Therefore improved removal of suspended solids and / or BOD would be expected to reduce the concentrations of metals in effluents.

7. There are likely to be particular difficulties in meeting more stringent consents for copper using conventional biological treatment even through improved removal of suspended solids and BOD. 


\section{REFERENCES}

Aarundel, J. sewage and Industrial Effluent Treatment. $2^{\text {nd }}$ Edition. Blackwell Science Ltd, 1-53, 2000.

Álvarez, E.A., Mochón, M.C., Sánchez J.C.J. and Rodríguez M.T. Heavy metal extractable forms in sludge from wastewater treatment plants. Chemosphere, 47, 765-775, 2002.

Barnes, D. Interferences in the electroanalytical determination of copper and lead in water and waste water. J. Water Treat. Exam., 24, 318-325, 1975.

Barth, E.F., Ettinger, M.B., Salotto, B.V. and McDermott, G.N. Summary report on the effects of heavy metals on the biological treatment processes. J. Water Pollut. Control Fed., 37, 86, 1965.

Bartling, S., Odnevall Wallinder, I., Leygraf, C. and Berggren, D. Immobilization of copper in runoff water from roofing materials by limestone, soil and concrete. Proc. $15^{\text {th }}$ Internat. Corrosion Conf., Granada, Spain, 2002.

Bergbäck, B., Johansson, K. and Mohlander, U. Urban metal flows - a case study of Stockholm. Review and conclusions. Water Air Soil Pollut. Focus, 1, 3-24, 2001.

Birkett, J.W. and Lester, J.N. Endocrine disrupters in wastewater and sludge treatment processes. CRC Press LLC, Boca Raton, Florida, USA, pp.312, 2003. 
Birkett, J.W. and Lester, J.N. Factors influencing the distribution of mercury and methylmercury in the sediments of a lowland river system. Proc. R. Soc. A, 461, 13351355, 2005.

Birkett, J.W. and Lester, J.N. Microbiology and Chemistry for Environmental Scientists and Engineers. E. \& F.N. Spon, London, pp.386, 1999.

Borja, A., Galparsoro I., Solaun O., Muxika I., Tello E.M., Uriarte A. and Valencia V. The European Water Framework Directive and the DPSIR, a methodological approach to assess the risk of failing to achieve good ecological status. Est. Coastal Shelf Sci., 66, 84-96, 2006.

Boulay, G. The WFD dreams: between ecology and economics. Water Environ. J. 22, 235240, 2008.

Boulay, N. and Edwards, M. Copper in the Urban Water Cycle. Crit. Rev. Environ. Sci. Technol., 30, 297-326, 2000.

Brown, H.G., Hensley, C.P., McKinney, G.L. and Robinson, J.L. Efficiency of heavy metals removal in municipal sewage treatment plants. Environ. Technol. Lett., 5, 103, 1973.

Brown, M. and Lester, J.N. Role of bacterial extracellular polymers in metal uptake in pure bacterial culture and activated sludge - I. Effects of metal concentration. Water Res., 16, 1539-1548, 1982a. 
Brown, M. and Lester, J.N. Role of bacterial extracellular polymers in metal uptake in pure bacterial culture and activated sludge - II. Effects of mean cell retention time. Water Res., 16, 1549-1560, 1982b.

Brown, M.J. and Lester, J.N. Metal removal in activated sludge: the role of bacteria extracellular polymers. Water Res., 3, 817-837, 1979.

Bubb, J.M. Rudd, T. and Lester, J.N. Distribution of heavy metals in the River Yare and its associated Broads. I. Mercury \& Methyl Mercury. Sci. Total Environ., 102, 147-168, 1991.

Buzier, R., Tusseau-Vuillemin, M.H., dit Meriadec, C.M., Rousselot, O. and Mouchel, J.M. Trace metal speciation and fluxes within a major French wastewater treatment plant: Impact of the successive treatments stages. Chemosphere, 65, 2419-2426, 2006.

Campbell P.G.C., Kreamer, L.D., Giguere, A., Hare, L. and Hontela, A. Subcellular Distribution of Cadmium and Nickel in Chronically Exposed Wild Fish: Inferences Regarding Metal Detoxification Strategies and Implications for Setting Water Quality Guidelines for Dissolved Metals. Hum. Ecol. Risk Assess., 14, 290-316, 2008.

Chang, L.Y. A waste minimization study of a chelated copper complex in wastewater: treatability and process analysis. Waste Manag., 15, 209-220, 1995.

Chen, K.Y., Young, C.S. and Rohatgi, N. Trace metals in wastewater effluents. J. Water Pollut. Control Fed., 46, 2663, 1974. 
Cheng, M.H., Patterson, E.R. and Minear, R.A. Heavy metals uptake by activated sludge. J. Water Pollut. Control Fed. 47, 362-376, 1975.

Cheng, S. Heavy metal pollution in China: origin, pattern and control. Environ. Sci. Pollut. Res. Int., 10, 192-198, 2003.

Chipasa, K.B. Accumulation and fate of heavy metals in biological wastewater treatment system. Waste Manage., 23, 135-143, 2003.

Chua, H., Yu, P.H.F., Sin, S.N. and Cheung, M.W.L. Sub-lethal effects of heavy metals on activated sludge microorganisms. Chemosphere, 39, 2681-2692, 1999.

Comber, S.D.W. and Gunn, A.M. Heavy metals entering sewage treatment works from domestic sources. J. Ch. Inst. Water Environ. Manage., 10, 137-142, 1996.

Correljé, A., François, D. and Verbeke T. Integrating water management and principles of policy: towards an EU framework? J. Cleaner Prod., 15, 1499-1506, 2007.

Crane M., Kwok, K.W.H., Wells, C., Whitehouse, P. and Lui, G.C.S. Use of field data to support European Water Framework Directive quality standards for dissolved metals. Environ. Sci. Technol., 41, 5014-5021, 2007.

Croston, N.J., Bubb, J.M. and Lester, J.N. Spatial distribution and seasonal changes in methylmercury concentrations in shallow lakes. Hydrobiologia, 321, 35-45, 1996. 
Davis, J.A. and Jacknow, J. Heavy metals in wastewater in three urban areas. J. Water Pollut. Control Fed., 47, 2292, 1975.

de Oliveira-Filho, E.C., Lopes, R.M. and Paumgartten, F.J.R. Comparative study on the susceptibility of freshwater species to copper-based pesticides. Chemosphere, 56, 369-374, 2004.

de Schamphelaere, K.A.C., Vasconcelos, F.M., Tack, F.M.G., Allen, H.E. and Janssen, C.R. Effect of dissolved organic matter source on acute copper toxicity to Daphnia magna. Environ. Toxicol. Chem., 23, 1248-1255, 2004.

Dudgeon D., Arthington A.H., Gessner M.O., Kawabata Z., Knowler D.J., Lévêque C., Naiman R.J., Prieur-Richard A.H., Soto D., Stiassny M.L. and Sullivan C.A. Freshwater biodiversity: importance, threats, status and conservation challenges. Biol. Rev., 81, 163$182,2005$.

Environment Agency. Environmental facts and figures: Dangerous Substances Directive. (http://www.environment-agency.gov.uk/yourenv/eff/1190084/water/213902/ 290690/290939/290981/?lang=_e). Accessed: 15.08.2008.

Eckenfelder Jr., W.W., Industrial water Pollution Control. McGraw-Hill Book Company, Singapore, 400pp, 1989.

Ekster, A. and Jenkins, D. Nickel and copper removal at the san Jose/Santa Clara water pollution control plant. Water Environ. Res., 68, 1172-1178, 1996. 
Esmond, S.E. and Petrasek, A.C. Trace metal removal. Ind. Water Eng., 8, 869, 1974.

European Commission. Council Directive 76/464/EEC of 4 May 1976 on pollution caused by certain dangerous substances discharged into the aquatic environment of the Community. OJ L129, 18.05.1976, 1-23, 1976.

European Commission. Decision No 2455/2001/EC of the European Parliament and of the Council of 20 November 2001 establishing the list of priority substances in the field of water policy and amending Directive 2000/60/EC. OJ L331, 15.12.2001, 1-5, 2001.

European Commission. Directive 2000/60/EC of the European Parliament and of the Council of 23 October 2000 establishing a framework for Community action in the field of water policy. OJ L327, 22.12.2000, 1-72, 2000.

European Commission. Directive 2006/11/EC of the European Parliament and of the Council of 15 February 2006 on pollution caused by certain dangerous substances discharged into the aquatic environment of the Community. OJ L64, 04.03.2006, 52-59, 2006.

European Commission. Proposal for a Directive of the European Parliament and of the Council on environmental quality standards in the field of water policy and amending Directives 82/176/EEC, 83/513/EEC, 84/156/EEC, 84/491/EEC, 86/280/EEC and 2000/60/EC. 2006/0129 COD, 10732/08, 23.06.2008, 1-32, 2008. 
Fatoki, O.S. Biomethylation in the natural environment: A review. S. Afr. J. Sci., 93, 366368, 1997.

Flemming, H.-C. Sorption sites in biofilms. Water Sci. Technol., 32, 27-33, 1995.

Förstner U. Environmental quality standards (EQS) applicable to sediment and/or biota. J. Soil Sediments, 7, 270, 2007.

Goldstone, M.E., Kirk, P.W.W. and Lester, J.N. The behaviour of heavy metals during wastewater treatment. I. Cadmium, chromium and copper. Sci. Total Environ., 95, 233252, 1990a.

Goldstone, M.E., Atkinson, C., Kirk, P.W.W. and Lester, J.N. The behaviour of heavy metals during wastewater treatment. III. Mercury and arsenic. Sci. Total Environ., 95, 271-294, 1990b.

Goldstone, M.E., Kirk, P.W.W. and Lester, J.N. The behaviour of heavy metals during wastewater treatment. II. Lead, nickel and zinc. Sci. Total Environ., 95, 253-270, 1990c.

Gothberg, A. and Greger, M. Formation of methyl mercury in an aquatic macrophyte. Chemosphere, 65, 2096-2015, 2006.

Gray N.F. Water Technology: An Introduction for Environmental Scientists and Engineers. 2 $2^{\text {nd }}$ Edition. Elsevier, 368-385, 2005. 
Groombridge, B. and Jenkins, M.D. Global Biodiversity. Earth's living resources in the $21^{\text {st }}$ century. World Conservation Press, Cambridge, pp. 246, 2000.

Handy, R.D. Chronic effects of copper exposure versus endocrine toxicity: two sides of the same toxicological process? Comp. Biochem. Physiol. A-Mol. Integr. Physiol., 135, 25-38, 2003.

Hawksworth, D.L. and Kalin-Arroyo, M.T. Magnitude and distribution of biodiversity. In Global Biodiversity Assessment. Ed. Heywood V.H. Cambridge University Press, 107-191, 1995.

Henson, M.C. and Chedrese, P.J. Endocrine disruption by cadmium, a common environmental toxicant with paradoxical effects on reproduction. Exp. Biol. Med., 229, 383-392, 2004.

Hsieh, C.Y., Tsai, M.H., Ryan, D.K. and Pancorbo, O.C. Toxicity of the 13 priority pollutant metals to Vibrio fisheri in the Microtox (R) chronic toxicity test. Sci. Total Environ., 320, 37-50, 2004.

Hu, Z., Chandran, K., Grasso, D. and. Smets, B.F. Effect of nickel and cadmium speciation on nitrification inhibition. Environ. Sci. Technol., 36, 3074-3078, 2002.

Hu, Z., Chandran, K., Grasso, D. and. Smets, B.F. Impact of metal sorption and internalization on nitrification inhibition. Environ. Sci. Tecbnol., 37, 728-734, 2003. 
Hunter, M., Stephenson, J.N., Lester, J.N. and Perry, R. The influence of transient phenomena on the biodegradation of nitrilotriacetic acid in the activated sludge process I: Variations in hydraulic loading and sewage strength. Water Air Soil Pollut., 25, 415430, 1985.

Isaac, R.A., Gil, L., Cooperman, A.N., Hulme, K., Eddy, B., Ruiz, M., Jacobson, K., Larson, C., and Pancorbo, O.C. Corrosion in drinking water distribution systems: a major contributor of copper and lead to wastewaters and effluents. Environ. Sci. Technol., 31, 3198-3203, 1997.

Itoh, H., Iwasaki, M., Nakajima, Y., Endo, Y., Hanaoka, T., Sasaki, H., Tanaka, T., Yang, B. and Tsugane, S. A case-control study of the association between urinary cadmium concentration and endometriosis in infertile Japanese women. Sci. Total Environ., 402, $171-175,2008$

Kallis, G. and Butler, D., The EU water framework directive: measures and implications. Water Policy, 3, 125-142, 2001.

Karvelas, M., Katsoyiannis, A. and Samara, C. Occurrence and fate of heavy metals in the wastewater treatment process. Chemosphere, 53, 1201-1210, 2003.

Kelly, C.J., Tumsaroj, N. and Lajoie, C.A. Assessing wastewater metal toxicity with bacterial bioluminescence in a bench-scale wastewater treatment system. Water Res., 38, 423-431, 2004. 
Kempton, S., Sterritt, R.M. and Lester, J.N. Factors affecting the fate and behaviour of toxic elements in the activated sludge process. Environ. Pollut. (Series A), 32, 51-78, 1983.

Kempton, S., Sterritt, R. and Lester, J.N. Heavy metal removal in primary sedimentation. I. The influence of metal solubility. Sci. Total Environ., 63, 231-246, 1987a.

Kempton, S., Sterritt, R. and Lester, J.N. Heavy metal removal in primary sedimentation. II. The influence of metal speciation and particle size distribution. Sci. Total Environ., 63, 247-258, $1987 b$.

Kirk, P.W.W., Perry, R., Hunter, M. Lester, J.N. and Matthews, P.J. Phosphorus removal by pre-precipitation of sewage: metal removal, sludge characteristics and treatment efficiency. Environ. Technol. Lett., 9, 171-180, 1988.

Klein, L.A., Lang M., Nosh M., and Kirschner, S. L. Sources of metals in New York City wastewater. J. Water Pollut. Control Fed., 46, 2653-2662, 1974.

Knepper, T.P. Synthetic chelating agents and compounds exhibiting complexing properties in the aquatic environment. Trends Anal. Chem., 22, 708-724, 2003.

Koch, C.M., Stroka, J.G., Perna, R.K. and Foerster, R.E. Impact of pretreatment on sludge content of heavy metals. J. Water Pollut. Control Fed., 54, 339, 1982.

Koch, M. and Rotard, W. On the contribution of background sources to the heavy metal content of municipal sewage sludge. Water Sci. Technol., 43, 67-74, 2001. 
Lake, D., Kirk, P.W.W. and Lester, J.N. The fractionation, characterization and speciation of heavy metals in sewage sludge and sludge-amended soils: a review. $J$. Environ. Qual., 13, 175-183, 1984.

Lake, D.L., Kirk, P.W.W. and Lester, J.N. Heavy metal solids association in sewage sludge. Water Res., 23, 285-291, 1989.

Landner, L. and Reuther, R. Metals in society and in the environment. A critical review of current knowledge on fluxes, speciation, bioavailability and risk for adverse effects of copper, chromium, nickel and zinc. Kluwer Academic Publishers, Netherlands, pp. 406, 2004.

Landner, L., Walterson, E. and Hellstrand, S. Copper in sewage and soil: A literature review and critical discussion of disposal of copper-containing sludges to agricultural land. International Copper Association, 2000.

Lawson, P.S., Sterritt, R.M. and Lester, J.N. Adsorption and complexation mechanisms of heavy metal uptake in activated sludge J. Chem. Technol. Biotechnol., 34B, 253-262, 1984b.

Lawson, P.S., Sterritt, R.M. and Lester, J.N. Factors affecting the removal of metals during activated sludge wastewater treatment. I. The role of soluble ligands. Archives of Environ. Contam. Toxicol., 13, 383-390, 1984c. 
Lawson, P.S., Sterritt, R.M. and Lester, J.N. Factors affecting the removal of metals during activated sludge wastewater treatment. II. The role of the mixed liquor biomass. Archives of Environ. Contam. Toxicol., 13, 391-402, 1984d.

Lawson, P.S., Sterritt, R.M. and Lester, J.N. The speciation of metals in sewage and activated sludge effluent. Water Air Soil Pollut., 21, 387-402, 1984a.

Le Quesne, T. and Green, C. Can we afford not to? The cost and benefit of a partnership approach to the Water Framework Directive. WWF-UK, pp. 29, 2005.

Legret, M. and Pagotto, C. Evaluation of pollutant loadings in the runoff waters from a major rural highway. Sci. Total Environ., 235, 143-150, 1999.

Lester, J.N. Editor. Heavy Metals in Wastewater and Sludge Treatment Processes. Volume I. Sources, Analysis and Legislation. CRC Press Inc., Boca Raton, USA, pp. 183, 1987a.

Lester, J.N. Editor. Heavy Metals in Wastewater and Sludge Treatment Processes. Volume II. Treatment and Disposal. CRC Press Inc., Boca Raton, USA, pp. 155, $1987 \mathrm{~b}$.

Lester, J. N. Fate and behaviour of heavy metals in the Whitlingham sewage treatment works, Norwich. Report to Anglian Water, Imperial College, London, pp.126, 1987c.

Lester, J.N. and Birkett, J.W. (Eds.) Microbiology and chemistry for environmental scientists and engineers. E \& F Spon, London, UK, pp. 386, 1999. 
Lester, J.N. and Edge, D. Sewage and Sewage Sludge Treatment. In: Pollution: Causes, Effects and Control. Harrison, R.M. (Ed.), Royal Society of Chemistry, Cambridge, 113-168, 2001

Lester, J.N. Significance and Behaviour of Heavy Metals in Waste Water Treatment Processes. I. Sewage Treatment and Effluent Discharge. Sci. Total Environ., 30, 1-44, 1983.

Lester, J.N., Harrison, R.M. and Perry, R. The balance of heavy metals through a sewage treatment works. I. Lead, cadmium and copper. Sci. Total Environ., 12, 13-23, 1979.

Lester, J.N., Sterritt, R.M. and Kirk, P.W.W. Significance and behaviour of heavy metals in waste water treatment processes. II. Sludge treatment and disposal. Sci. Total Environ., 30, 45-83, 1983

Liao, B.Q., Allen, D.G., Droppo, I.G., Leppard, G.G. and Liss, S.N. Surface properties of sludge and their role in bioflocculation and settleability. Water Res., 35, 339-350, 2001.

Liu, Y., Lam, M.C. and Fang, H.H.P. Adsorption of heavy metals by EPS of activated sludge. Water Sci. Technol., 43, 59-66, 2001.

Lundberg J.G., Kottelat M., Smith G.R., Stiassny M.L.J. and Gill A.C. So many fishes, so little time: an overview of recent ichthyological discovery in continental waters. Ann. Miss. Bot. Garden., 87, 26-62, 2000. 
Madoni, P., Davoli, D. and Gorbi, G. Acute toxicity of lead, chromium, and other heavy metals to ciliates from activated sludge plants. Bull. Environ. Contam. Toxicol., 53, 420425, 1994.

Madoni, P., Esteban, G. and Gorbi, G. Acute toxicity of cadmium, copper, mercury, and zinc to ciliates from activated sludge plants. Bull. Environ. Contam. Toxicol., 49, 900-905, 1992.

Malaney, G.W., Sheets, W.D. and McQuillen, R. Toxic effects of metallic ions on sewage micro-organisms. J. Water Pollut. Control Fed., 31, 1309, 1959.

Malmqvist, B. and Rundle, S. Threats to the running water ecosystems of the world. Environ.Conserv., 29, 134-153, 2002.

Medesani, D.A., Greco, L.S.L. and Rodriguez, E.M. Interference of cadmium and copper with the endocrine control of ovarian growth, in the estuarine crab Chasmagnathus granulata. Aquat. Toxicol., 69, 165-174, 2004.

Metcalf and Eddy Inc. Wastewater Engineering: Treatment and Reuse. $4^{\text {th }}$ Edition. McGraw-Hill, 361-411, 2004.

Meyer, J., Schmidt, A., Michalke, K. and Hensel, R. Volatilization of metals and metalloids by the microbial population of an alluvial soil. Syst. Appl. Microbiol., 30, 229238, 2007. 
Michalke, K., Wickenheiser, E.B., Mehring, M., Hirner, A.V. and Hensel, R. Production of Volatile Derivatives of Metal(loid)s by Microflora Involved in Anaerobic Digestion of Sewage Sludge. Appl. Environ. Microb., 66, 2791-2796, 2000.

Minnow Environmental Inc. Environmental Risk-Based Approaches for Managing Municipal Wastewater Effluent (MWWE). Minnow Environmental Inc., pp. 16-23, 2005.

Mitsuo, C., Kyoshi, M., Hiroshi, S. and Tadahiro, M. The amount of heavy metals derived from domestic sources in Japan. Water, Air, and Soil Poll., 57-58, 829-837, 1991.

Mowat, A. Measurement of metal toxicity by Biochemical oxygen demand. J. Water Pollut. Control Fed., 48, 853, 1976.

Nagase, H., Ose, Y., Sato, T. and Ishikawa, T. Mercury methylation by compounds in humic material. Sci. Total Environ., 32, 147-156, 1984.

Neufeld, R.D. and Hermann, E.R. Heavy metal removal by acclimated sludge. J. Water Pollut. Control Fed., 47, 310-329, 1975.

Neufeld, R.D. Heavy metals induced deflocculation of activated sludge. J. Water Pollut. Control Fed., 48, 1940, 1976.

Obeng, L.A., Lester, J.N. and Perry, R. Effect of Mixed liquor suspended solids concentration on the biodegradation of nitrilotriacetic acid in the activated sludge process. Chemosphere, 10, 1005-1009, 1981. 
Obeng, L.A., Perry, R. and Lester, J.N. The influence of transient temperature changes on the biodegradation of nitrilotriacetic acid in the activated sludge process. Environ. Pollut. (Series A), 28, 149-1611, 1982.

Oliveira, A.S., Bocio, A., Beltramini Trevilato, T.M.,. Magosso Takayanagui, A.M., Domingo, J.L. and Segura-Muñoz S.I. Heavy metals in untreated/treated urban effluent and sludge from a biological wastewater treatment plant. Environ. Sci. Pollut. Res., 14, 483-489, 2007.

Oliver, B.G. and Cosgrove, E.G. The efficiency of heavy metal removal by a conventional activated sludge treatment plant. Water Res., 8, 869, 1974.

Olson, B.H., Lester, J.N., Cayless, S.M. and Ford, S. Distribution of mercury resistance determinants in bacterial communities of river sediments. Water Res., 23, 1209-1217, 1989.

Pane, E.F., Smith, C., McGeer, J.C. and Wood, C.M. Mechanisms of acute and chronic waterborne nickel toxicity in the freshwater cladoceran, Daphnia magna. Environ. Sci. Technol., 37, 4382-4389, 2003.

Pongratz, R. and Heumann, K.G. Production of methylated mercury and lead by polar macroalgae - A significant natural source for atmospheric heavy metals in clean room compartments. Chemosphere, 36, 1935-1946, 1998. 
Pongratz, R. and Heumann, K.G. Production of methylated mercury, lead, and cadmium by marine bacteria as a significant natural source for atmospheric heavy metals in polar regions. Chemosphere, 39, 89-102, 1999.

Poon, C.S. and Chu, C.W. The use of ferric chloride and anionic polymer in the chemical assisted primary sedimentation process. Chemosphere, 39, 1573-1582, 1999.

Raposo, J.C., Ozamiz, G., Etxebarria, N., Tueros I., Muñoz C., Muela, A., Arana, I. and Barcina I. Mercury biomethylation assessment in the estuary of Bilbao (North of Spain). Environ.Pollut., 146, 1-7, 2008.

Reid, W., Barber, C. and Miller, K., Global Biodiversity Strategy. Guidelines for Action to Save, Study, and Use Earth's Biotic Wealth Sustainably and Equitably. World Resources Institute, pp. 7-18, 1992.

Ricciardi, A. and Rasmussen J.B. Extinction Rates of North American Freshwater Fauna. Conserv. Biol.,, 13, 1220-1222, 1999.

Ridge, A.C. and Sedlak, D.L. Effect of ferric chloride addition on the removal of $\mathrm{Cu}$ and Zn complexes with EDTA during municipal wastewater treatment. Water Res., 38, 921932, 2004.

Roberts, P., Hegi, H.R., Webber, A. and Kradhenbahl, H.R. Metals in municipal waste water and their elimination in sewage treatment. Prog. Water Technol., 8, 301, 1977. 
Rossin, A.C., Sterritt, R.M. and Lester, J.N. The influence of process parameters on the removal of heavy metals in activated sludge. Water Air Soil Pollut., 17, 185-198, 1982a.

Rossin, A.C., Lester, J.N. and Perry, R. Removal of nitrilotriacetic acid during primary sedimentation and its effect on metal removal. Environ. Pollut., 4, 315-330, $1982 \mathrm{~b}$.

Rossin, A.C., Perry, R. and Lester, J.N. The removal of nitrilotriacetic acid and its effect on metal removal during biological sewage treatment. I. adsorption and acclimatization. Environ. Pollut. (Series A), 29, 271-3021, 1982c.

Rossin, A.C., Lester, J.N. and Perry, R. The removal of nitrilotriacetic acid during biological sewage treatment and its effect on metal removal. II. Under shock loading. Environ. Pollut. (Series A), 30, 1-26, 1983 a.

Rossin, A.C., Sterritt, R.M. and Lester, J.N. The influence of flow conditions on the removal of heavy metals in the primary sedimentation process. Water Air Soil Pollut., 19, 105-121, 1983b.

Rudd, T., Sterritt, R.M. and Lester, J.N. Stability constants and complexation capacities of complexes formed between heavy metals and extracellular polymers from activated sludge. J. Chem. Tech. Biotech., 33A, 374-380, 1983a.

Rudd, T., Sterritt, R.M. and Lester, J.N. Mass balance of heavy metal uptake by encapsulated cultures of Klebsiella aerogenes. Microb. Ecol., 9, 261-272, 1983b. 
Rudd, T., Sterritt, R.M. and Lester, J.N. Formation and conditional stability constants of complexes formed between heavy metals and bacterial extracellular polymers. Water Res., 18, 379-384, 1984.

Rudd, T., Lake, D.L., Mehrota, I., Sterritt, R.M., Kirk, P.W.W., Campbell, J.A. and Lester, J.N. Characterisation of metal forms in sewage sludge by chemical extraction and progressive acidification. Sci. Total Environ., 74, 149-175, 1988.

Rule, K.L., Comber, S.D.W., Ross, D., Thornton, A., Makropoulos, C.K. and Rautiu, R. Survey of priority substances entering thirty English wastewater treatment works. Water Environ. J., 20, 177-184, $2006 a$.

Rule, K.L., Comber, S.D.W., Ross, D., Thornton, A., Makropoulos, C.K. and Rautiu, R. Diffuse sources of heavy metals entering an urban wastewater catchment. Chemosphere, 63, 64-72, 2006b.

Russo, R.C. Development of marine water quality criteria for the USA. Mar. Pollut. Bull., 45, 84-91, 2002.

Sala, O.E., Chapin III, F.S., Armesto, J.J., Berlow, E., Bloomfield, J., Dirzo, R., HuberSanwald, E., Huenneke, L.F., Jackson, R.B., Kinzig, A., Leemans, R., Lodge, D.M., Mooney, H.A., Oesterheld, M., Poff, N.L., Sykes M.T., Walker, B.H., Walker M. and Wall, D.H. Global Biodiversity Scenarios for the Year 2100. Science, 287, 1770-1774, 2000. 
Santarsiero, A., Veschetti, E., Donati, G. and Ottaviani M. Heavy Metal Distribution in Wastewater from a Treatment Plant. Microchem. J., 59, 219-227, 1998.

Scancar, J., Milacic, R., Strazar, M. and Burica O. Total metal concentrations and partitioning of $\mathrm{Cd}, \mathrm{Cr}, \mathrm{Cu}, \mathrm{Fe}, \mathrm{Ni}$ and $\mathrm{Zn}$ in sewage sludge. Sci. Total Environ., 250, 919, 2000.

Semerjian, L. and Ayoub, G.M. High-pH-magnesium coagulation-flocculation in wastewater treatment. Adv. Environ. Res., 7, 389-403, 2003.

Shoham-Frider, E., Shelef, G. and Kress, N. Mercury speciation in sediments at a municipal sewage sludge marine disposal site. Marine Environ. Res., 64, 601-615, 2007.

Sonune A. and Ghate R. Development in wastewater treatment methods. Desalination, 167, 55-63, 2004.

Sorme, L. and Lagerkvist, R. Sources of heavy metals in urban wastewater in Stockholm. Sci. Total Environ., 298, 131-145, 2002.

Sorme, L., Lindqvist, A. and Soderberg, H. Capacity to influence sources of heavy metals to wastewater treatment sludge. Environ. Manage., 31, 421-428, 2003.

Spath, R., Flemming, H.C. and Wuertz, S. Sorption properties of biofilms. Water Sci. Technol., 37, 207-210, 1998. 
Stander, L and Theodore, L. Environmental Regulatory Calculations Handbook. John Wiley \& Sons Inc., New Jersey, 561pp, 2008.

Stasinakis, A.S., Thomaidis, N.S., Mamais, D., Karivali, M. and Lekkas, T.D. Chromium species behaviour in the activated sludge process. Chemosphere, 52, 1059-1067, 2003.

Stephenson, T., Lawson, P.S., Rudd, T., Sterritt, R.M. and Lester, J.N. Mechanism of metal removal in activated sludge. J. Environ. Eng., 113, 1074-1088, 1987.

Stephenson, T. and Lester, J.N. Heavy Metal behaviour during the activated sludge process. II: Insoluble metal removal mechanisms. Sci. Total Environ., 63, 215-230, 1987.

Stephenson, T., Perry, R. and Lester, J.N. The influence of transient phenomena on the biodegradation of nitrilotriacetic acid in the activated sludge process II: Variations in influent metal and NTA concentrations. Water Air Soil Pollut., 25, 431-450, 1985.

Sterritt, R.M., Brown, M.J. and Lester, J.N. Metal removal by adsorption and precipitation in the activated sludge process. Environ. Pollut. (Series A), 24, 313-323, 1981.

Sterritt, R.M. and Lester, J.N. The value of sewage sludge to agriculture and effects of the agricultural use of sludge contaminated with toxic elements: a review. Sci. Total Environ., 16, 55-90, 1980a.

Sterritt, R.M. and Lester, J.N. Interactions of heavy metals with bacteria. Sci. Total Environ., 14, 5-17, 1980b. 
Sterritt, R.M. and Lester, J.N. Atomic absorption spectrophotometric analysis of the metal content of waste water samples. Environ. Technol. Lett., 1, 402-417, 1980c.

Sterritt, R.M. and Lester, J.N. The influence of bacterial growth on the forms of cadmium in defined culture media. Bull. Environ. Contam. Toxicol., 24, 196-203, 1980d.

Sterritt, R.M. and Lester, J.N. Concentrations of heavy metals in forty sewage sludges in England. Water Air Soil Pollut.,14, 125-131, 1981a.

Sterritt, R.M. and Lester, J.N. The influence of sludge age on heavy metal removal in the activated sludge process. Water Res., 15, 59-65, $1981 \mathrm{~b}$.

Sterritt, R.M. and Lester, J.N. Speciation of copper and manganese in effluents from the activated sludge process. Environ. Pollut. (Series A), 27, 37-44, 1982.

Sterritt, R.M. and Lester, J.N. Significance and behaviour of heavy metals in waste water treatment processes. III. Speciation in waster waters and related complex matrices. Sci. Total Environ., 34, 117-141, 1984a.

Sterritt, R.M. and Lester, J.N. Comparison of methods for the determination of conditional stability constants of heavy metal-fulvic acid complexes. Water Res., 18, 1149-1153, 1984b.

Stonebrook, H., Kerr, J., Newell, G. and Ferell, L. Case history of industrial pretreatment in Columbus, Ohio. J. Water Pollut. Control Fed., 56, 1093-1098, 1984. 
Stoveland, S., Astruc, M., Lester, J.N. and Perry, R. The balance of heavy metals through a sewage treatment works. II. Chromium, nickel and zinc. Sci. Total Environ., 12, 25-34 1979a.

Stoveland, S., Lester, J.N. and Perry, R. The influence of nitrilotriacetic acid on heavy metal transfer in the activated sludge process. I. At constant loading. Water Res., 13, 949-965, $1979 b$.

Stoveland, S., Perry, R. and Lester, J.N. The influence of nitrilotriacetic acid on heavy metal transfer in the activated sludge process. II. At varying and shock loadings. Water Res., 13, 1043-1054, 1979c.

Stoveland, S. and Lester, J.N. A study of the factors which influence metal removal in the activated sludge process. Sci. Total Environ., 16, 37-54, 1980.

Stover, R.C., Sommers, L.E. and Silviera, D.J. Evaluation of metals in wastewater sludges. J. Water Pollut. Control Fed., 48, 2165, 1976.

Takiguchi, M. and Yoshihara, S. New aspects of cadmium as endocrine disruptor. Environ. Sci., 13, 107-116, 2006.

Tebbutt, T.H.Y. and Christoulas, D.G. Performance relationships for primary sedimentation. Water Res., 9, 347-356, 1975. 
Tomlinson, T.G., Boon, A.G. and Trotman, C.N.A. Inhibition of nitrification in the activated sludge process of sewage disposal. J. Appl. Bacteriol., 29, 266, 1966.

UKTAG (UK Technical Advisory Group on the Water Framework Directive). Proposals for environmental quality standards for Annex VIII substances. SR1-2007, final draft, pp. 77, 2007.

USEPA. National Recommended Water Quality Criteria. Office of Water, Office of Science and Technology, 4304T, pp. 24, 2006.

USEPA. Aquatic life ambient freshwater quality criteria - copper. Office of Water, Office of Science and Technology, EPA-822-R-07-001, pp. 41, 2007.

Verma, M.M., Wan, L.W. and Prasad, C. Acclimation of wastewater bacteria by induction or mutation selection. J. Water Pollut. Control Fed., 48, 832, 1976.

Wang, W.X. and Rainbow, P.S. Subcellular partitioning and the prediction of cadmium toxicity to aquatic organisms. Environ. Chem., 6, 395-399, 2006.

WCED (World Commission on Environment and Development). Our Common Future. Oxford, Oxford University Press, pp. 416, 1987.

Weber, J.H. Review of possible paths for abiotic methylation of mercury(II) in the aquatic environment. Chemosphere, 26, 2063-2077, 1993. 
Whitehouse, P. Measures for Protecting Water Quality: Current Approaches and Future Developments. Ecotox. Environ. Safe., 50, 115-126, 2001.

Wukasch, R.F., Yost, K.J. and Michalczyk, B.C.. Distribution of heavy metals within a sewage treatment plant. In Municipal Sludge Management, Proc. $8^{\text {th }}$ Natl. Conf., Information Transfer, Silver Springs, Md., USA, 1979.

Yeoman, S., Sterritt, R.M., Rudd, T. and Lester, J.N. Particles size fractionation and metal distribution in sewage sludge. Water Air Soil Pollut., 45, 27-42, 1989.

Yost, K.J. and Wukasch, R.F. Pollutant sources and flows in a municipal sewage system. Environ. Monit. Assess., 3, 61-76, 1983.

Zitko, V. Structure-activity relations and the toxicity of trace elements to aquatic biota. In Workshop on Toxicity to Biota of Metal Forms in Natural Waters, Great Lakes Research Advisory Board, Canada, 1975. 